\title{
A geological concept of the map sheet Rønde based on dynamic structures
}

By Kaj Strand Petersen and

Leif Aabo Rasmussen
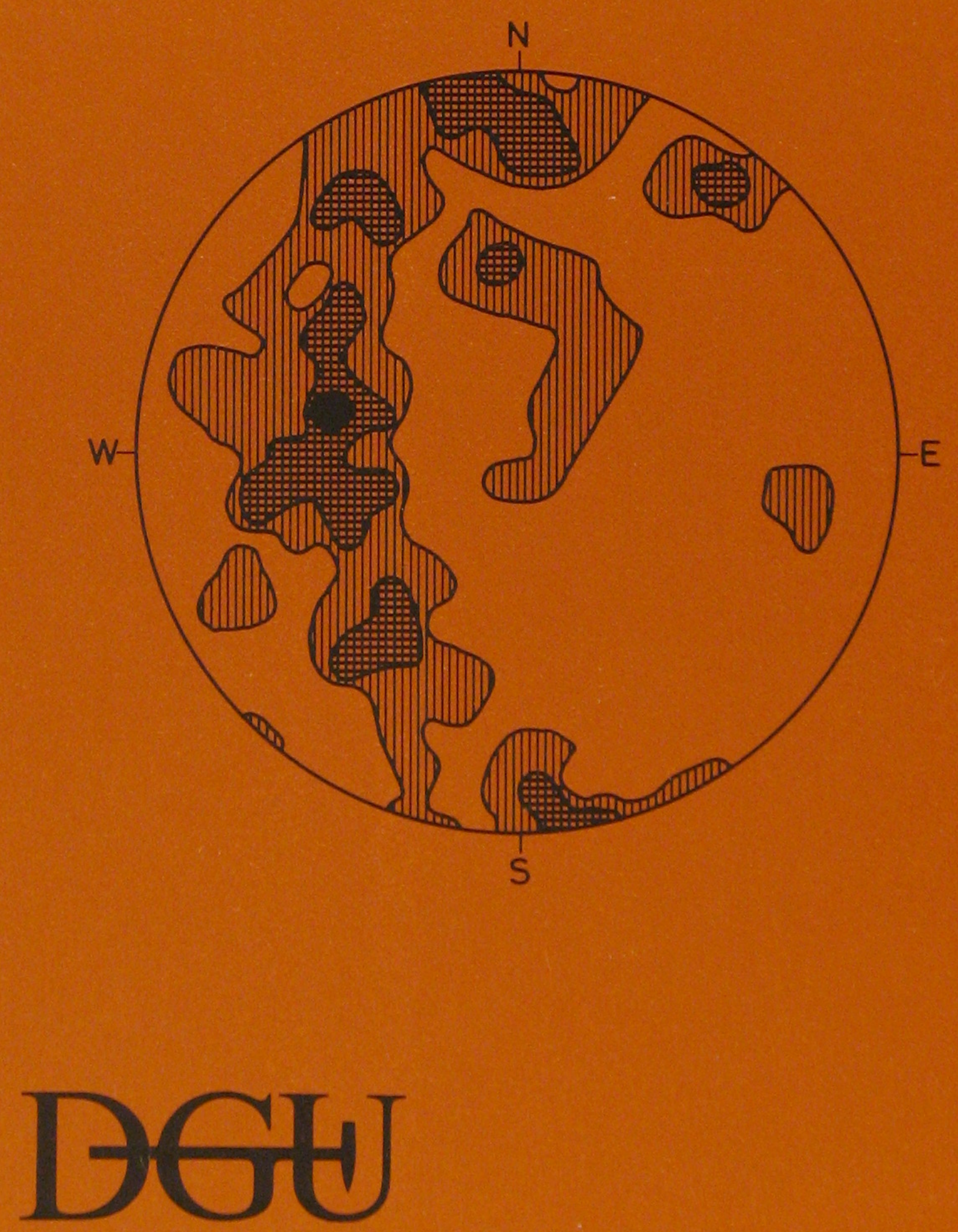

Geological Survey of Denmark

Ministry of the Environment

1987 


\section{A geological concept of the map sheet $R ø$ nde based on dynamic structures}

Geological mapping of 1315 II

Rønde Djursland, Denmark

By Kaj Strand Petersen and

Leif Aabo Rasmussen

February 1987

DGU series $C$ no. 8

ISBN 87-88640-01-9

ISSN 0900-6362 
Key words :

Denmark, Djursland, Dynamic structures, Fabric analyses, Holocene, Kineto-stratigraphy, Mapping, Morphology, Paleogene, Pleistocene, Sea-level

Vignette:

Fabric diagram from the Middle Pleistocene till unit

DGU Series C no. 8

ISBN 87-88640-01-9

ISSN $0900-6362$

Oplag: 750

Tryk: DGU, Offset og Ryvang Bogtryk

Tegninger, plancer og kort: Torben Friis Jensen

Kaj Strand Petersen

Leif Aabo Rasmussen

Redaktør: Ole Valdemar Vejbæk

(C) Danmarks Geologiske Unders $\varnothing$ gelse

Thoravej 31, 2400 København NV 


\section{CONTENTS}

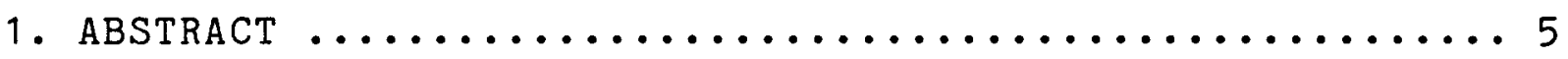

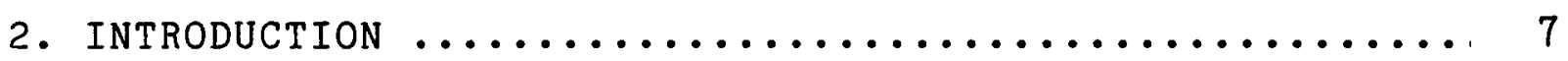

2.1. Description of the research programme $\ldots \ldots \ldots \ldots 7$

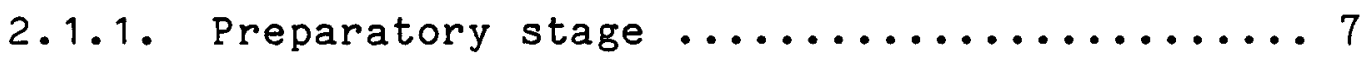

2.1.2. Mapping stage $\ldots \ldots \ldots \ldots \ldots \ldots \ldots \ldots \ldots \ldots$

2.1.3. Processing stage $\ldots \ldots \ldots \ldots \ldots \ldots \ldots \ldots \ldots$

3. THE MAIN TOPOGRAPHIC UNITS $\ldots \ldots \ldots \ldots \ldots \ldots \ldots \ldots \ldots \ldots \ldots$

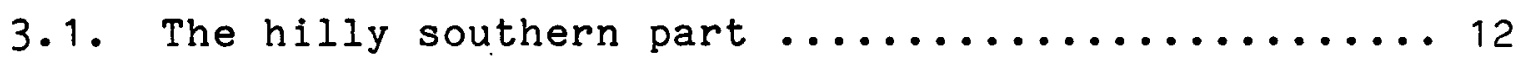

3.2. The lake and stream systems $\ldots \ldots \ldots \ldots \ldots \ldots \ldots 12$

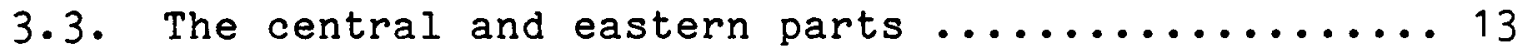

3.4. The levelled northern part .................. 13

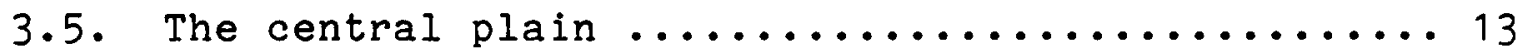

4. OUTLINE ON THE PREQUATERnary $\ldots \ldots \ldots \ldots \ldots \ldots \ldots \ldots \ldots$

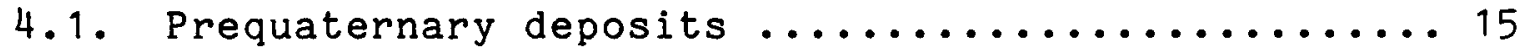

4.1.1. Paleocene deposits ................ 16

4.1.2. Eocene deposits .................. 16

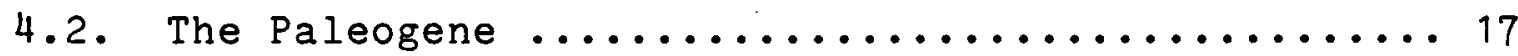

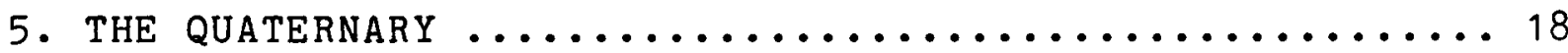

5.1 Quaternary deposits ................... 18

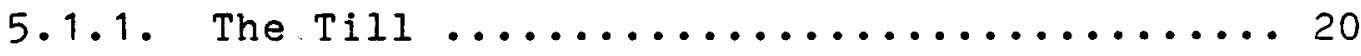

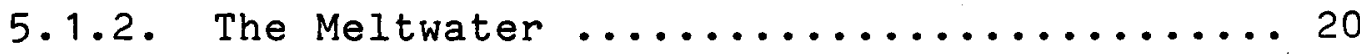

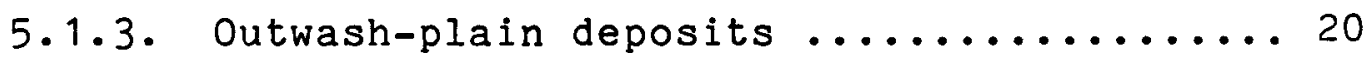

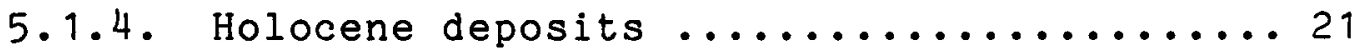

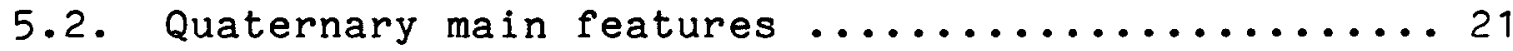

5.2.1. Pleistocene main features .............. 21

5.2.2. Holocene main features ............. 22

5.3. The Pleistocene deposits on the map sheet ......23

5.4. The Holocene deposits on the map sheet $\ldots \ldots \ldots .26$ 
6. STRATIGRAPHICAL AND SPATIAL POSITION OF UNITS $\ldots \ldots \ldots 28$ 6.1. Middle Pleistocene deposits ................. 30

6.2. Late Pleistocene deposits ..................... 31 6.2.1. NE kineto-stratigraphic drift unit .... 33 6.2.2. S kineto-stratigraphic drift unit ..... 41

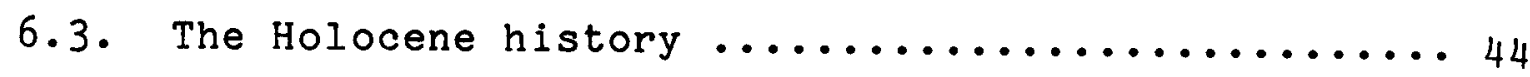
6.3.1. Freshwater and peat deposits ........ 45 6.3 .2 . The Littorina fjord stages .......... 46

7. CONCLUSIVE REMARKS $\ldots \ldots \ldots \ldots \ldots \ldots \ldots \ldots \ldots \ldots \ldots \ldots$

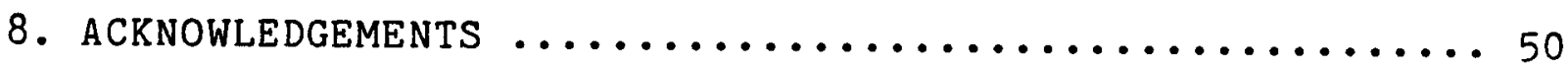

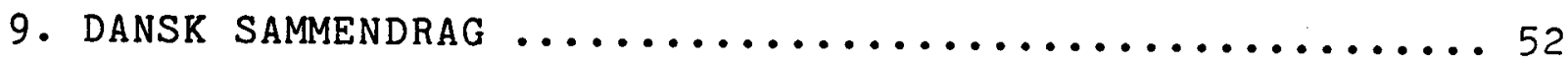

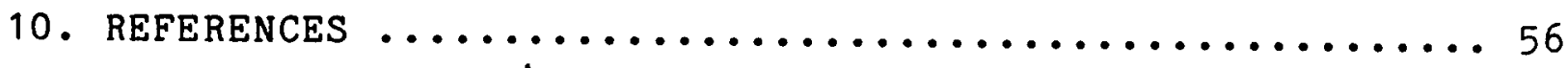

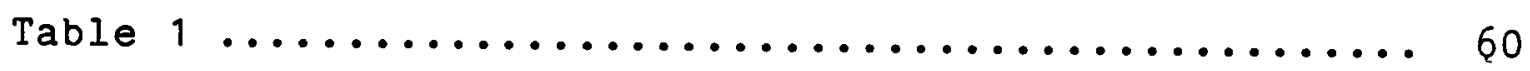

Enclosure: The map sheet 1315 II Rønde 


\section{ABSTRACT}

During the mapping of the map sheet Rønde 1315 II an important kineto-stratigraphical frame for the Late Middle Weichselian in the central part of Denmark was demonstrated. Quaternary units are deposited on Paleogene sediments consisting of clayey Eocene-Paleocene strata to the southwest and Lower Paleocene-Danian limestone to the northeast. Middle Pleistocene till units are found as erosional remnants on the Prequaternary surface. The Late Pleistocene deposits are described within the kineto-stratigraphical concept, showing an older unit related to a glacial advance from the northeast and a younger one from the south, both belonging to the Late Middle Weichselian glaciation. Prominent extramarginal outwash sand deposits cover the central part of the map sheet as a part of the drift unit from the south.

The low-lying areas have been covered by the sea during the Holocene from the transgression in Early Atlantic up to the end of Subboreal. In the Subatlantic, freshwater deposits were formed, later covered by peat. 


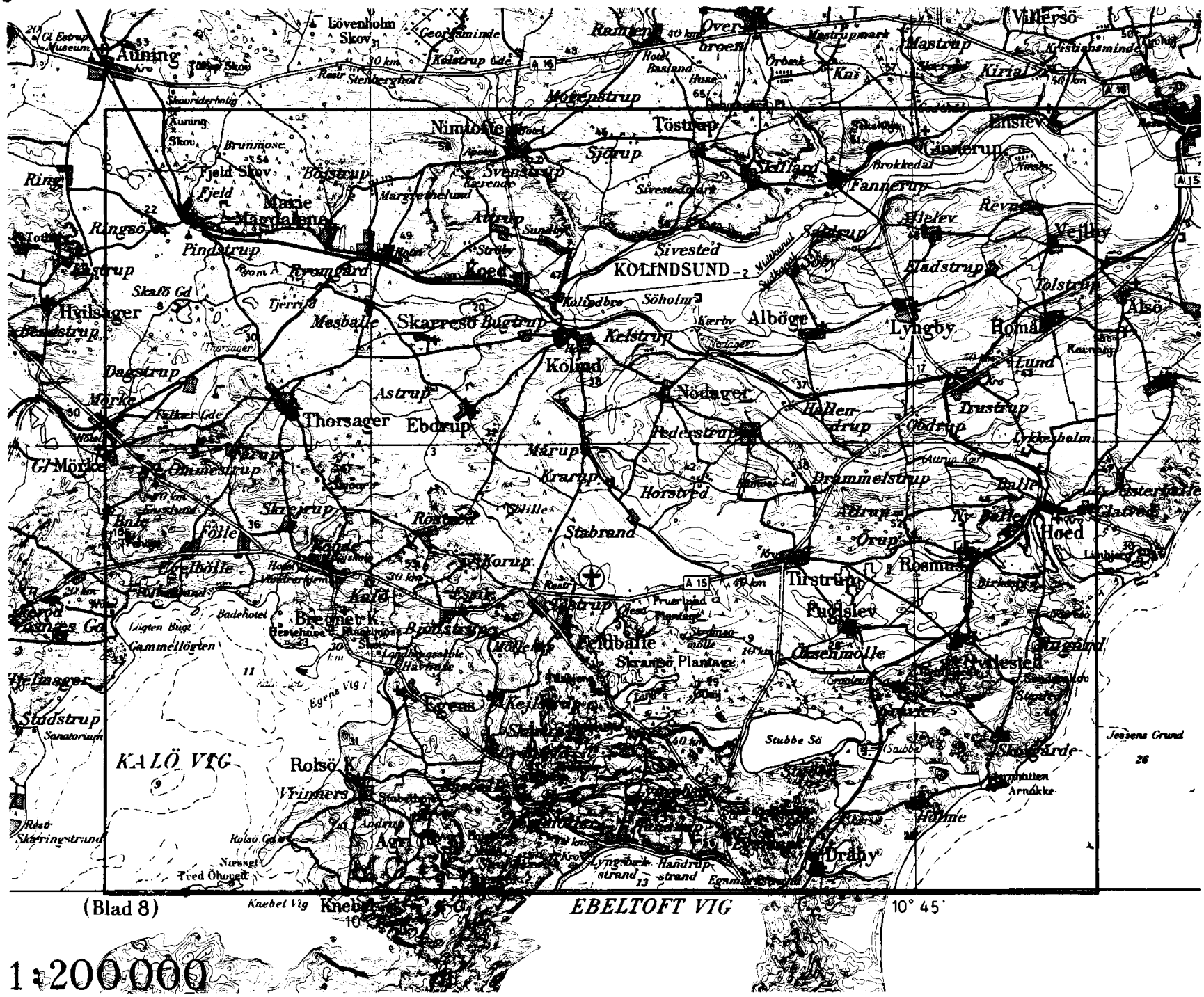

Fig. 1. Location map 1315 II Rønde. Reproduced with the permission of the Geodetic Institute ( $A .881 / 71)$.

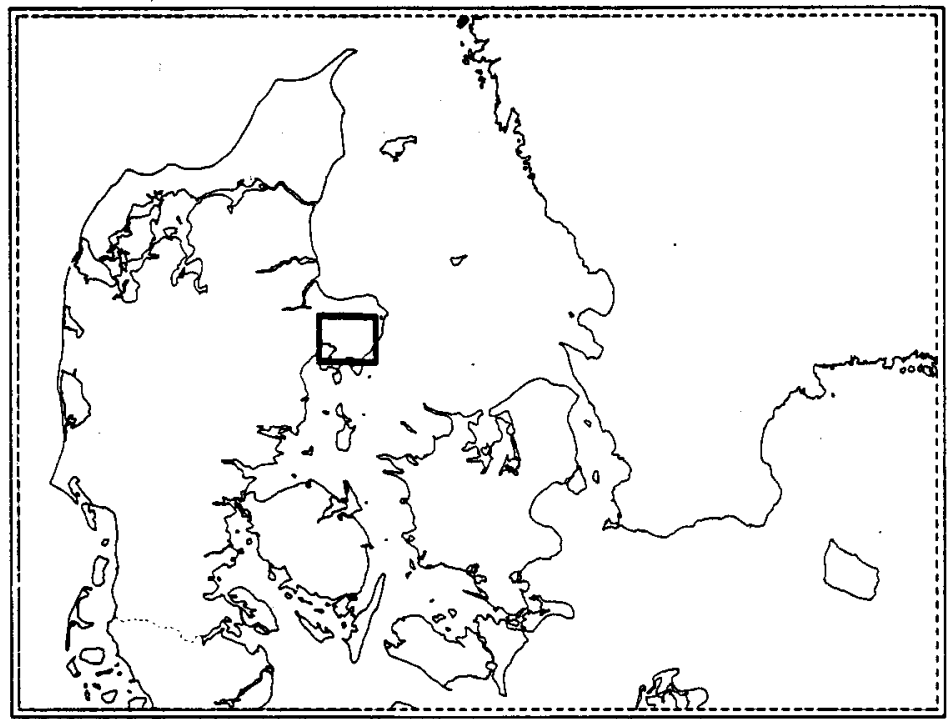




\section{INTRODUCTION}

During the planning process of phase 2 of the Vulnerability Project, ENV 703 DK, it was proved that obviously the mapping in connection with the verification of the preliminary vulnerability maps was completely dependent on the accuracy of the geological model of the actual area: "The geological model stating the spatial extension of the aquifera" as expressed by Sønderskov \& Hansen (1984). The knowledge and details of the lithology and the deposition features are complex especially in the central and southern part of Djursland. Furthermore the area has not previously been geologically mapped by the Geological Survey of Denmark, who are responsible for the geological mapping of the country. However, the Mols Bjerge has been investigated by Rasmussen (1977). It was therefore decided to carry through the mapping of map sheet 1315 II Rønde (fig. 1).

\subsection{Description of the research programme}

The following procedure was employed during the mapping of map sheet 1315 II Rønde. The research programme was divided into three stages:

\subsubsection{Preparatory stage}

During the preparatory phase preceding the actual field work, all available data in the Survey archives concerning the chosen map sheet were used to compile a model of the geology of the area. These data included maps drawn in connection with hydrogeological studies carried out throughout the county of Arhus (1977). 
The preparatory stage was concluded with the drawing up of a primary geological model for the area.

\subsubsection{Mapping stage}

During the field mapping phase detailed examination of the geological sections played a prominent part, since the mapping project is intended to achieve a three-dimensional representation of the surface formations. After a structural interpretation, severely dislocated strata within the area often provide insight into the more complete succession of the sediments present (Petersen 1978). A general picture of the Iithological succession provides a better opportunity for the field geologist to establish models of the structure and correct the stratigraphy of the area.

The mapping of the area was carried out by means of a $1 \mathrm{~m}$ auger, using a sample density of 100-200 $\mathrm{m}$, depending on the complexity of the area.

During the field mapping, a limited number of deeper additional exploratory wells were made to provide insight into the stratigraphic sequence of the area. The drillings were, if possible, sunk to the bedrock surface. Samples were retained every $1 / 2 \mathrm{~m}$.

During the mapping, samples of the various units were obtained, and they were lithologically determined in the field. The samples from the drillings and from the field work have been subjected to sedimentological, lithological as well as macro and micropalaeontological analyses. Fabric analyses of the till units were undertaken, and palaeocurrent measurements are taken from the meltwater deposits. Analyses and measurements together with the reconstruction of ice-push directions were used to establish the stratigraphy and the geological events, the so-called kineto-stratigraphic units (cf. Berthelsen 1973, 1978). 


\subsubsection{Processing stage}

During the processing phase, the geological map was drawn on the scale of $1: 25,000$ and became available for planning authorities. In this connection the map sheets 1315 II NV Ryomgård, 1315 II SV Rønde, 1315 II $N \emptyset$ Kolindsund and 1315 II $S \emptyset$ Tirstrup were completed the summer of 1985.

The final map on the scale of $1: 50,000$ accompanying the report was completed the autumn of 1985. The geological interpretation and the internal report were finished in February 1986 by Petersen and Rasmussen in connection with the Vulnerability Project. 


\section{THE MAIN TOPOGRAPHIC UNITS}

1315 II Rønde covers part of the southern Djursiand peninsula on the east coast of Jutland (fig. 1). The town of Rønde is situated at $56^{\circ} 18^{\circ} \mathrm{N}$ and $10^{\circ} 30^{\circ} \mathrm{E}$ of Greenwich. The area reaches the Kattegat to the east and the two bays of Kal $\varnothing \mathrm{Vig}$ and Ebeltoft Vig to the south. The main topographic units are shown on fig. 2.

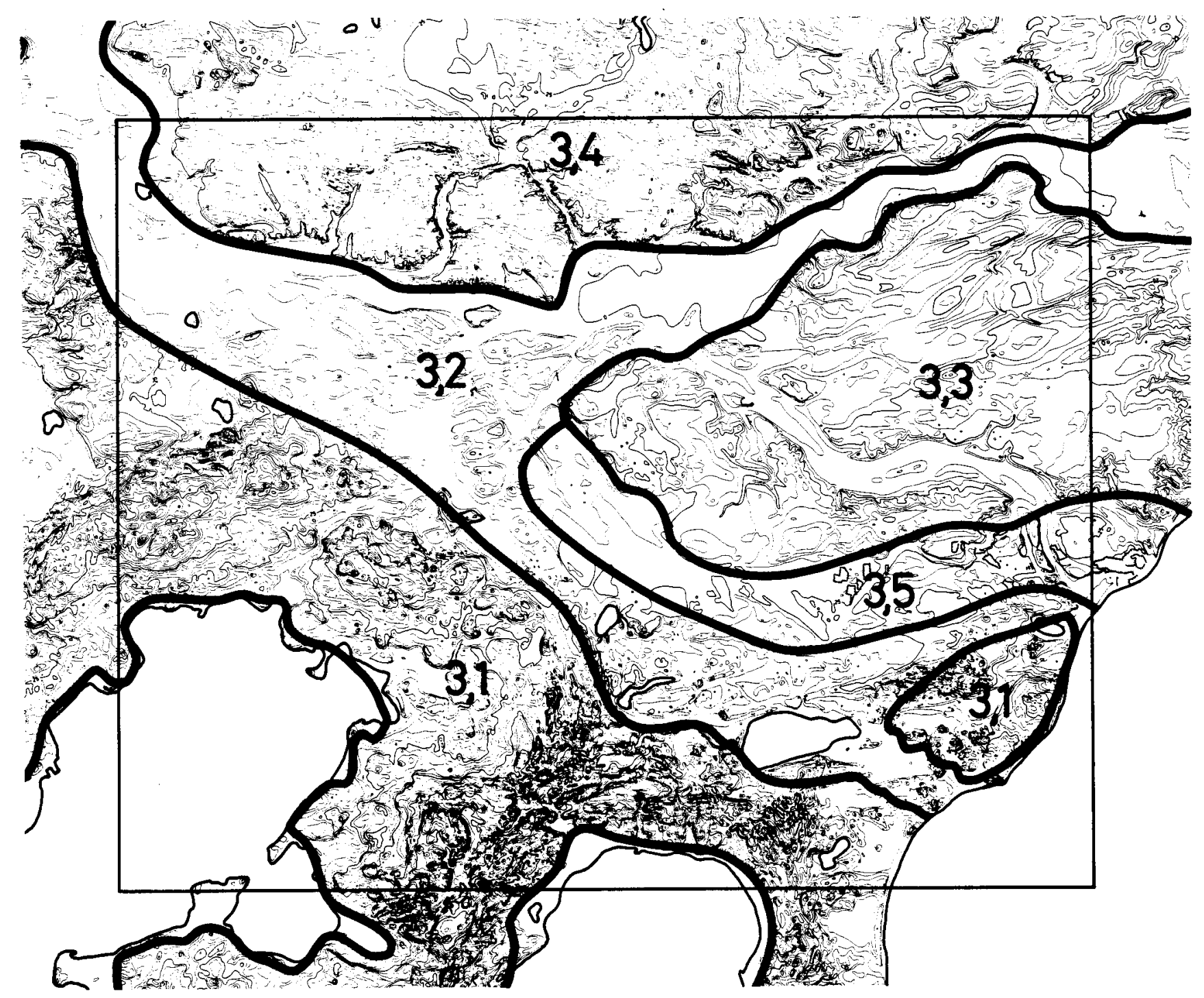

Fig. 2. The main topographic units: 3.1. The hilly southern part, 3.2. The lake and stream systems, 3.3. The central and eastern parts, 3.4. The levelled northern part, and 3.5. The central plain. Reproduced with the permission of the Geodetic Institute (A.881/71). 


\subsection{The hilly southern part}

The highest elevation on the Rønde map sheet is reached in the southern part which separates the two bays of Kalø Vig and Ebeltoft Vig, viz. Agri Bavnehøj $(137 \mathrm{~m})$ on the peninsula of Mols. Similar hights are found to the northeast around Rønde $(102 \mathrm{~m})$ and Trehøje $(106 \mathrm{~m})$ in the western part of the map sheet. To the east the hights are more restrained, such as north of the Ebeltoft Vig at Handrup $(84 \mathrm{~m})$, but still the elongation of the hills is in conformity with the border of the bay.

Further to the northeast towards the Kattegat coasts hights of $66 \mathrm{~m}$ (Gratbjerg) and $49 \mathrm{~m}$ (Jernhatten) are found in somewhat isolated hilly complexes. Here the present Stubbe $S \varnothing$ at a level of $2 \mathrm{~m}$ is connected with the Kattegat which is situated $4 \mathrm{~km}$ further east.

\subsection{The lake and stream systems}

Stubbe $S \varnothing$ is part of a chain of minor lakes found to the northwest: Langs $\varnothing, \emptyset$ jes $\varnothing$ and the now reclaimed Korups $\varnothing$. The Korups $\varnothing$ area, at a level of $3 \mathrm{~m}$, is drained by Korup A towards the north through Elløv Enge and then eastwards through Kolindsund debouching into the Kattegat at Grena. However, the depression can be followed northwest of Elløv Enge in a series of bogs: Kastrup Mose and Pindstrup Mose which are drained by Ryom $A$ also towards the east through Kolindsund.

In the northwesternmost part of the map sheet at Auningkær at a level of $5 \mathrm{~m}$ the depression is at the present time drained towards the north through Vejle $\AA$ and Alling $A$ to Randers Fjord.

The intersection of the above-mentioned lake and stream systems north of the hilly part of the map sheet leaves two elevated areas which form the northern and the central to eastern parts of the map sheet. 
The central part from Kolind to Tirstrup has an elevation of about $40^{\circ} \mathrm{m}$, and it is cut of $\mathrm{f}$ fom the eastern part by the river valley of Skoda (from Attrup Kær to Kærby). In the eastern part elongated hills of a northeast-southwestern direction reach hights of about $40 \mathrm{~m}$.

\subsection{The levelled northern part}

The northern part has a level between 50 and $60 \mathrm{~m}$ intersected by several streams which run towards the south into the Kolindsund drainage system.

\subsection{The central plain}

Apart from the reclaimed grounds, such as Kolindsund and Korups $\varnothing$, the only plain to be found is the area from Rosmus via Tirstrup and Stabrand to Marup in the central part of the map sheet. This area forms a slightly tilted plain which over at distance of $15 \mathrm{~km}$ falls from an elevation of $30 \mathrm{~m}$ at Rosmus to $15 \mathrm{~m}$ at Mårup.

The main topographic units consequently consist of the hilly southern part, the lake and stream systems, the central and eastern parts with elongated hills, the levelled northern part, and the plain from the eastern part of the map sheet at Rosmus to the central part at Marup (see fig. 2).

It must be stressed that this division into topographic units is solely based upon the topography. Consequently reflections on the geological implications according to units appears in the division on table 1, discussed in chapter 6 (p. 28 ) on stratigraphical and spatial position of units. 


\section{OUTLINE ON THE PREQUATERNARY}

The Prequaternary formations at the base of the Pleistocene and Holocene within the Rønde map sheet belong to the Paleogene (Sorgenfrei \& Buch 1964). These Lower Tertiary deposits belong to the Eocene and the Paleocene of which only the Danian stage is found cropping out in the northeasternmost part of the map sheet at Enslev ( $\mathrm{fig}$. 1). However, late Paleocene and Eocene deposits are often found as floes in the drift in the southern part of the Rønde map sheet. The floes are up to $20 \mathrm{~m}$ thick and stretching out for several hundred metres. This might imply that the transportation has only been slight. Such floes are found at Ommestrup southeast of Mørke, at Rønde, and at several places in the western part of Mols. According to Rasmussen (1977) more than 50 sites with Eocene plastic clay are found on the Mols peninsula. The plastic clay with tuff beds was due to the presence of dinoflagellates regarded as belonging to the Upper Paleocene (Heilmann-Clausen 1982). However, recently Heilmann-Clausen (1986) wrote: "A preliminary correlation of volcanic ash layers (Knox 1984) indicates that the boundary (Paleocene/Eocene) is probably close to the base of the $\emptyset$ lst Formation (NP10 Zone). Knox correlates the ash sequence of the $\emptyset$ lst Formation with a sequence of ash layers in DSDP Hole 550 in the North Atlantic, SW of Ireland. The ashes at this site falls entirely in the NP10 Zone, i.e. in the Eocene".

\subsection{Prequaternary deposits}

The succession of the Prequaternary strata is well established by the deep test well Rønde No. 1 situated $2 \mathrm{~km}$ west of Rønde (Rasmussen et al. 1971). It has a final depth of $-5,244 \mathrm{~m}$. At the final depth basalt, fine-grained, brown to redish-brown was found belonging to Upper Silurian. At the base of the Quaternary deposits of 'sand and clayey till, Eocene sticky clay is found at a depth of $+8 \mathrm{~m}$. This might have been glacially 
transported, but at $-1 \mathrm{~m}$ the Røsnæs clay is in situ, and $6 \mathrm{~m}$ further down beds of volcanic ash occur. At a depth of between -209 and $-265 \mathrm{~m}$ the transition to Upper Cretaceous is found.

\subsubsection{Paleocene deposits}

Along the Kattegat coast from Jernhatten towards the northeast up to Rugård, Paleocene deposits have been known for a long time (Grönwall \& Harder 1907). The cliff exposures clearly show that the sequence of Quaternary and Paleogene strata has been dislocated by the ice.

Further on along the coast but outside the map sheet Danian limestone is found forming the cliff at Bredstrup Klint. However, the covering till in the northeastern part of the map shows such strong traces of chalk that it can be characterized as a lime till ( $K M L$ or $K M G$ ). Also the outwashed sediments (TS-TG) found in the Glatved-Balle-Rosmus area and in the central eastern part of the map contain large quantities of Danian limestone. These deposits have been exploited for many hundred years for lime burning, and many old-fashioned lime kilns are found in the area.

Also the Paleocene deposits found south of a line from Rugård, Tirstrup, Thorsager and Mørke have been exploited by the brick-making industry and used for marl for soils with lime requirements (Milthers 1919). The Paleocene sequence consists of fine-grained minerals which are $<0.02 \mathrm{~mm}$ in the lower part and become more clayey in the upper part (Gry 1935). In the uppermost part lime-free strata are found (Hansen \& Andersen 1969).

\subsubsection{Eocene deposits}

The Eocene plastic clay is a very sticky deposit with a grain size of $<0.001 \mathrm{~mm}$. The lowermost part contains ash layers and 
is at the present time again referred to the Eocene sequence, as discussed in chapter 4 (p. 15 ).

\subsection{The Paleogene}

As stated by Dinesen et al. (1977): "With the exception of the limestone strata of the Danian stage and the sandier Oligocene deposits, sticky impermeable clay and marl sediments of marine origin are almost universal throughout the Lower Tertiary of Denmark".

Considering that the Quaternary erosional boundary of the Paleocene, not including the Danian limestone, is trending diagonal northwest/southeast across the Rønde map sheet (op. cit. Plate 5) with limestone to the northeast and up to $50 \mathrm{~m}$ of sticky Eocene-Paleocene deposits to the southwest, it is obvious that the Prequaternary deposits give rise to many of the differences within the drift deposits which will be dealt with in the chapters to follow. 


\section{THE QUATERNARY}

The collecting of samples of the unconsolidated Quaternary rocks is carried out by means of a soil auger which penetrates the top of the ground to a depth of $1 \mathrm{~m}$. The determinations are made in the field by the geologists.

The mapping geologist operates with Pleistocene (glacial and late-glacial) and Holocene (postglacial) sediments (fig. 3 ). Aeolian deposits may belong to either of these periods.

Most categories are divided into four intervals of grain sizes (clay/silt/sand/gravel) from clayey to gravelly. In postglacial freshwater and marine deposits the organogene content of gyttja, peat and seaweed is marked as well.

An introduction to various terms for Danish sediments is given by Bornebusch \& Milthers (1935). However, the main guidelines of the terms used in Denmark will be given below.

\subsection{Quaternary deposits}

Denmark is part of the downwarping area of the North Sea, where, in the central part, about $1,000 \mathrm{~m}$ of Quaternary sediments have accumulated. Furthermore, the area is placed within the submarginal zone of the Quaternary glaciations, and as a result of this up to $200 \mathrm{~m}$ of sediments have accumulated during the Late Pleistocene. The maximum extension of the Weichselian glaciation, the Main Stationary Line, goes through Denmark (Ussing 1903; Petersen 1985b fig. 5). 


\section{LEGEND}

LETTER

SYMBOLS

FT

FP

FL

FI

FS

FG

FK

FJ

HT

HV

HP

$\mathrm{HL}$

HI

HS

HG

EI

ES

TL

TI

TS

TG

YL

YI

YS

YG

ZL

$\mathrm{ZI}$

ZS

ZG

DL

DI

DS

DG

$M L$

MI

MS

MG

KML

KMG

K

PL
SEDIMENTS

\section{Quaternary deposits}

freshwater -peat

-gyttja

-clay

-silt

-sand

-gravel

tuja, bog lime \& lake marl

ocher \& bog iron ore

marine

-sea weed

-marsh

-gyttja

-clay

-silt

-sand

-gravel

aeolian -clay/silt

-sand

freshwater -clay

-silt

-sand

-gravel

marine -clay

-silt

-sand

-gravel

glacial-lake -clay

-silt

-sand

-gravel

meltwater -clay

-silt

-sand

-gravel

till

-clayey

-silty

-sandy

-gravelly

lime till clayey

lime till gravelly

Prequaternary deposits

Danian limestone

Paleogene deposits

Fig. 3. Legend of Pleistocene and Holocene deposits. 
5.1.1. The Till

Clayey till (ML) is the dominating surface deposit in the southeastern part of Jutland and on the islands, including the island of Bornholm. In the northeastern part of Jutland sandy till (MS) dominates, and in northwestern Jutland clayey till is found.

Gravelly till (MG) is only met with locally, often in connection with moraines. Fine examples of this are found along the East Jutlandic Border Zone, which passes through the area under consideration (Petersen 1985b fig. 6).

\subsubsection{The Meltwater}

Meltwater deposits (DL, DI, DS and DG) are typically found where the covering till deposits have been eroded, viz. exposed on the sides of ravines. However, as large areas within the Danish territories are dislocated, older strata of gravel and sand may crop out on the surface. Eskers are represented, designated as meltwater deposits as well. Certain areas which were covered by the Weichselian glaciation are dominated by glacial-lake deposits (ZL and ZI).

\subsubsection{Outwash-plain deposits}

The late glacial marine deposits have only been mapped in northern Jutland. The freshwater deposits from the Pleistocene, with the designation of clay, silt, sand and gravel (TL, TI, TS and $T G$ ), are mainly found outside the Main Stationary Line, viz. the southwestern part of Jutland, where the outwash plains dominate the landscape. However, minor sandur deposits of a younger age are found in the eastern part of Denmark, e.g. Tirstrup sandur on the present map sheet. 


\subsubsection{Holocene deposits}

The postglacial marine deposits are to a great extent mapped over large areas in the northeastern part of Denmark where isostatic uplift has consolidated the former marine areas. The dominating sediments are here marine gyttja and sand (HP and HS) with prominently raised beach ridges of gravel (HG).

Major marsh deposits (HV) are only found along the southwestern coast of Jutland.

Apart from the naturally formed lake basin freshwater gyttja and peat are often found in former marine areas, where the regression of the sea leaves low-lying flat areas, and along rivers.

Aeolian (ES) deposits of great extent are found along the west coast of Jutland and in certain areas with meagre soil. Windblown sand can be referred to both Pleistocene and Holocene deposits as mentioned earlier.

\subsection{Quaternary main features}

The recurrence of ice caps over the Danish area during the Pleistocene, spreading from the central part of Scandinavia, contributed with a great variety of material from afar. Furthermore, the impact of ice cover has had an effect on the isostatic movements.

\subsubsection{Pleistocene main features}

According to older investigations, the Main Stationary Line, marking the maximum extent of the Weichselian glaciations, is found west of Djursland (Ussing 1907). This implies that the Rønde map sheet has been overrun by the ice forming this terminal moraine. A younger ice movement studied by Harder (1908) formed the moraine in East Jutland which can be followed 
through the southern part of the Rønde map sheet. The meltwater from the ice in the East Jutlandic Border Zone had a great influence on the water course of the area, and the central part of the Rønde map sheet is to a great extent characterized by extramarginal deposits of sand and gravel. The meltwater streams also intersected the older landscape left by the ice reaching the Main Stationary Line.

This landscape constitutes the central-eastern part with elongated hills and the levelled northern part on the Rønde map sheet.

\subsubsection{Holocene main features}

According to Mertz (1924) the Djursland peninsula belongs to the northeastern Danish area of isostatic uplift. This area is defined to. be north of the $0 \mathrm{~m}$ isobase running from Nissum Fjord to the southeast over Vejle and the island of Fyn to the northern part of Falster in the Baltic (see op. cit., map 1). The area in question is situated between the +3.0 and the +4.5 $\mathrm{m}$ isobase with beach ridges at hights of $3.1 \mathrm{~m}$ and $6.9 \mathrm{~m}$ respectively. The high value for the beach ridges towards northeast is caused by the exposure towards the Kattegat.

As might be deduced from the information in chapter 3.2 ( $p$. 12 ), the Stubbe $S \varnothing$ area at a level of $+2 \mathrm{~m}$, which is connected with the Kattegat, has been a fjord during the Littorina sea stage in the Holocene. Furthermore, the Korups $\varnothing$ area, at a level of $+3 \mathrm{~m}$, has been connected with the sea through the Kolindsund as figured by Jessen (1920, map 1). It appears that the northwesternmost part of the map sheet at Auningkær, at a level of $+5 \mathrm{~m}$, was part of the Littorina sea fjord stage. This implies that the Kolindsund fjord system in those days was a strait leading from Grena up to the present Randers Fjord. 


\subsection{The Pleistocene deposits on the map sheet}

Clayey till has been mapped in all parts of the map sheet, but the highest areal concentration is found in the southwestern hilly part of the Kalø Vig region. The grain size $<0.002 \mathrm{~mm}$, which dominates such a clayey till, is influenced by the sticky impermeable clay of Lower Tertiary origin. This clay also occurs in floes of such sizes that they have been mapped as single exposures (see chapter 4 ( $p .15$ )).

In the southeastern part clayey till dominates along the coastal region, and successions of tills (ML) are found overlying the Paleogene deposits seen in cliff exposures from Jernhatten to Rugård. Especially at the Sønderskov locality huge slidings occur within the area called Hullerne. The sliding is generated by the groundwater flow over the impermeable stiff Tertiary clay.

The central and eastern parts also have areas where clayey tili dominates, but within the region with elongated hills the character of the till is influenced by the high content of lime, designated as lime till (KML). The grain size of limestone/flint material (between 2 and $20 \mathrm{~mm}$ ) in the till may lead to the designation as gravelly lime till (KMG).

Other occurrences of gravelly till (MG) are found in patches along the hilly southern part of the map sheet, especially in the somewhat isolated hilly complex in the eastern part from Stubbe $S \varnothing$ towards Hyllested. Boulder concentrations were previously found within these regions, but many years of cultivation have removed these documents.

Sandy till with a dominating grain size between $0.006-2.0 \mathrm{~mm}$ is found especially in the levelled northern part of the map sheet and in minor areas from the western central area to the southeastern part of the map sheet. The areas of sandy till are often mapped where stony, unstratified sand, which contains hardly any lime, occurs. This sediment probably represents a surface till well washed out for its content of lime and clay. 
Meltwater sand is found all over the map sheet and is well sorted within the grain size $0.06-2.0 \mathrm{~mm}$. However, it occurs in various ways. In the western part of the southern hilly region meltwater sand is found in minor areas, partly in long ridges and partly in high-lying areas surrounded by the clayey till which characterizes the region.

To the east - from the eastern part of Mols over Handrup to Egsmark south of Stubbe $S \varnothing$ - meltwater sand is the dominating deposit. This includes the area with numerous kettle holes just west of Stubbe $S \varnothing$ (see map - kettle holes marked with crosses).

In the depression mentioned earlier, stretching from Stubbe $S \varnothing$ towards the northwest, the whole area is characterized by meltwater sand until around Thorsager. Furthermore it characterizes the low-lying part of the eastern region with elongated hills northwest of Trustrup.

In the eastern part of the levelled northern area meltwater sand is the dominating topmost sediment but further westwards around Nimtofte it occurs in the ravines overlain by sandy till. Between Pindstrup and Ryomgard in the west it occurs in patches alternating with meltwater gravel. In this area crescentically shaped hills are found where also gravelly till has been mapped.

In the southern part meltwater gravel is demonstrated in the area west of $\emptyset$ jes $\emptyset$ and Langs $\emptyset$ where another set of the crescentic hills are found. Otherwise meltwater gravel is rather rarely found within the map sheet.

There are several areas of meltwater clay in the western hilly part, especially between Rønde and Mørke. To the east the meltwater clay is found in the area characterized by the clayey till, and in the cliff exposures meltwater clay is found between till beds.

In the central and eastern areas with elongated hills, clay is found cropping out in the ravines and in the slopes of the 
Skodå-Hoed $\AA$ valley (from Hoed to Kerby). Wells were sunk in order to ascertain that these layers are found in the deeper strata of the area. Meltwater clay has not been mapped to any great extent in the northern levelled part of the map sheet.

Outwash-plain sand and gravel constitute the extramarginal deposits found south and west of the central and eastern parts with elongated hills from Glatved to Mårup. These deposits are furthermore found south and west of the levelled northern part of the map sheet from Kolind to Auningkær (south of Auning). In this part the outwash plain is partly cut by the younger marine and freshwater deposits and partly overgrown by peat. This situation reflects the tilted plain of this sandur deposit as mentioned in chapter 3.5 (p. 13). Considering the grain-size distribution within the whole stretch of this sandur, it appears that the outwash-plain gravel (TG $2-20 \mathrm{~mm}$ ) is concentrated in the Glatved-Tirstrup region. The outwash sand (TS $0.06-2.0 \mathrm{~mm}$ ) dominates farther to the northwest which also indicates that the proximal part of the sandur is situated in the eastern part of the map sheet.

Within the present Hoed $\AA$-Skoda valley outwash-plain deposits are found around Hoed at a level of $20 \mathrm{~m}$, falling to c. $5 \mathrm{~m}$ at the northern end of Skoda in the Kolindsund valley. According to the grain-size distribution within this system of terraces, the outwash-plain gravel is found also in the proximal part of the tilted plain system.

Outwash-plain sediments have not been found in the eastern part of Kolindsund, although the meltwater must have followed this valley as the terraces west of Kolind are far too high to be considered part of the skoda terraces.

It should be mentioned that during the last ten years downwash sediments have not been mapped as Pleistocene deposits as was done earlier. Such deposits are now mapped as freshwater sand carrying the same letter symbol as postglacial freshwater sand and gravel (FS and FG). This is due to the simple fact that during field work it is impossible on the basis of a single 
sample to distinguish between sand of late glacial and postglacial origin, and we must assume that downwash sediments were formed also during the Holocene. This consideration has also been applied to the windblown sand (ES). However, within this map sheet the aeolian deposits have different ways of occurrence. First within the low-lying lake/stream-sandur area and secondly along the coast on raised marine deposits of Holocene age. In the first case it might have a Pleistocene origin, and in the second case it is certainly of Holocene age.

\subsection{The Holocene deposits on the map sheet}

Among the Holocene deposits the freshwater sediments (FP and FS) and peat (FT) have by far the widest extension. In the southern hilly part numerous former lakes and bogs are found between the crescentic hills and in areas with kettle hole topography. In the western part of the northern area gyttja and peat are likewise very common. However, the very extensive areas of freshwater deposits are found in the lake and stream area partly covering the former fjord regions. The stubbe $S \varnothing$ area presents a good example of such a later freshwater and peat deposition which was previously connected with the Kattegat.

Examinations of the extensive, raised marine beaches (HG) towards the Kattegat show how the area was closed off from the sea by the building up of beach ridges of gravel, and freshwater deposits were formed. The former $\$ \varnothing n d e r s \emptyset$ just north of Sønderskov gives a good example of such a succession. Marine gyttja (HP) is found at the bottom, then comes a layer of freshwater gyttja, and finally the area was overgrown, and peat was formed: FT/FP/HP.

The true extension of the old Littorina fjord system is to some extent concealed by this younger freshwater deposit. However, it appears that in the Korups $\varnothing$ area marine gyttja (HP) and marine sand (HS) are still found. Macrofossils are studied in order to evaluate former environments. The molluscs have among 
other things permitted the conclusion on the environmental changes through the ages, which will be discussed in part of the next chapter.

The sediments found within the map sheet have been commented on, and their distribution has been pointed out to a certain degree. Some rarely used terms still remain to be mentioned, such as FK standing for tufa, bog lime as well as lake marl which occur now and then in small patches. Ocher and bog iron ore (FJ) have also been found, often in connection with tufa. Freshwater clay (FL) and marine clay (HL) have been mapped in previously quiet aquatic environments. Clayey deposits from the Holocene always contain some gyttja, which can be demonstrated by measuring the weight loss on ignition.

It has been proposed to increase the number of terms used during mapping by a grain-size designation for silt, 0.002-0.06 $\mathrm{mm}$, covering all the sediments both of Pleistocene and Holocene origin. However, it now appears to have been a mistake. Oniy meltwater silt ( $D I$ ) has been mapped to some degree in the field, all the other categories: silty till (MI), silty outwash-plain sediment etc. have not been observed. The silty aeolian sediment (EI) has only been recognized in very few places in Denmark. 


\section{STRATIGRAPHICAL AND SPATIAL POSITION OF UNITS}

At the base of the Quaternary strata the Early Paleocene (the Danian stage) is found in the northern part of the map sheet. According to well data the surface is found at a level of 10-20 $m$ below sea level rising towards the northeast.

South of the line from Hyllested, Stabrand, Thorsager to Mørke Late Paleocene is found at levels between +30 and $-50 \mathrm{~m}$, indicating a varying surface but within a stretch of $20 \mathrm{~km}$ in an east-west direction. From the northeastern part of the peninsula of Mols at Femmøller and towards the west the youngest part of the Paleogene, recognized on the map sheet, consists of Eocene clay. This includes the area around Rønde where the Prequaternary surface in the deep test well was found at $+8 \mathrm{~m}$ (see chapter 4.1 ( $p .15)$ ). It cannot be excluded that some of the well data, as depicted by Rasmussen (1977 table 2) reflect Paleogene strata occurring as floes in the drift. However, in the deep well at Rønde the Danian is found at a depth of $-87 \mathrm{~m}$, indicating a $95 \mathrm{~m}$ thick sequence of in situ Late Paleocene and Eocene rocks.

The general trend of the Danian surface is a dip towards the southwest where it is covered by still younger Paleogene deposits of marl and clay. Such a structural configuration of the Prequaternary strata is considered essential for the ice-tectonic features occurring in the area.

The extremely different bedrocks may to some extent account for the varying lithology of the Pleistocene deposits as outlined in chapter $5.3(\mathrm{p} .23)$.

The implications of the difference in the Prequaternary deposits are that lithology may vary to such a degree that correlation of till strata during field work may fail. However, 
reconstruction of the environments by way of measuring fabric, glacial striae and ice-push directions may provide us with a stratigraphy - the so-called kineto-stratigraphy as mentioned in chapter 2.1 .2 ( $p .8$ ). In combination or separately these methods have been used in all parts of the present glacial landscape.

In this investigation emphasis has been laid on till-fabric studies. These analyses are a valuable tool in glacial geology as an indicator of ice movement. In the field investigations are carried out in flat-lying or only slightly disturbed tills by measuring the direction and dip of 50 elongated clasts with lengths between $1-10 \mathrm{~cm}$. The measurements per sample are plotted on an equal-area grid net (lower hemisphere) and contoured using the method described by Kalsbeek (1963). Contours $1,2-3,>3$ points per 1 per cent area.

On the whole the till-fabric types can be divided into three types. The a-fabric is characterized by parallel long axes dipping gently towards the direction of the ice movement. The b-fabric is characterized by pebbles with long axes lying subhorizontally concentrated along directions transverse to the ice-flow direction. The mixed type called m-fabric contains elements of both a- and b-fabrics, the long axes usually lying on a gently upstream dipping girdle.

Glacial striae have been measured on glacial pavements in the till units.

The direction of the ice push is determined by studying the glaciotectonic structures of appropriate size and significance.

Measurements of palaeocurrents have been made in the outwash-plain sediments. These measurements sustain the information offered by the morphological features and the grain-size distribution as pointed out in chapter 5.3 ( $p .23$ ). However, information on age of the Pleistocene deposits by way of absolute dating has not been obtained within the map sheet apart from datings of the very youngest part of the Late Middle Weichselian glaciation indicating that the outwash plain of 
Tirstrup north of the East Jutlandic moraine was formed between 14,000 and 13,000 BP (Petersen 1984).

\subsection{Middle Pleistocene deposits}

The occurrence of a marine deposit between the tills at Rugård has with some reservations been referred to the Holsteinian on the basis of foraminiferal studies (Kronborg \& Knudsen 1985). The under-lying glacial sequence is consequently of Elsterian or older age, representing the oldest known Quaternary unit within the map sheet.

South of Sønderskov in the Rugard area fabric analyses have been made on this oldest till unit rich in limestone and flint. The strata in this profile very much resemble the sequence as presented by Kronborg \& Knudsen (op.cit. fig. 2). The whole sequence has been dislocated from the southeast, and the fabric diagram is adjusted for this. In the diagram from the lowermost till unit (fig. 4) it is seen that with respect to the majority of the pebbles, the long-axis are lying in or close to a plane, which intersects the lower hemisphere in a great circle. If, in the present case, a mechanism implying passive folding by means of inhomogeneous shear is applied, the direction af the shear movement which created the reorientation of the older lineation, i.e. the older fabric, was induced by an ice flow from the south-southeast towards the north-northwest (Nielsen 1981). (fig. 5 southwestern part of the map).

The till is characterized by the high content of limestone and flint as mentioned above, which also points to the Danian deposits found in the northern part of the area. However, this unit is not mappable in the field, but well data show that patches of an older till unit do occur on the Prequaternary surface. These pieces of information indicate that the older till units are erosional remnants on the Prequaternary surface. This in itself presents a good example of denudation through the earlier part of the Pleistocene. 


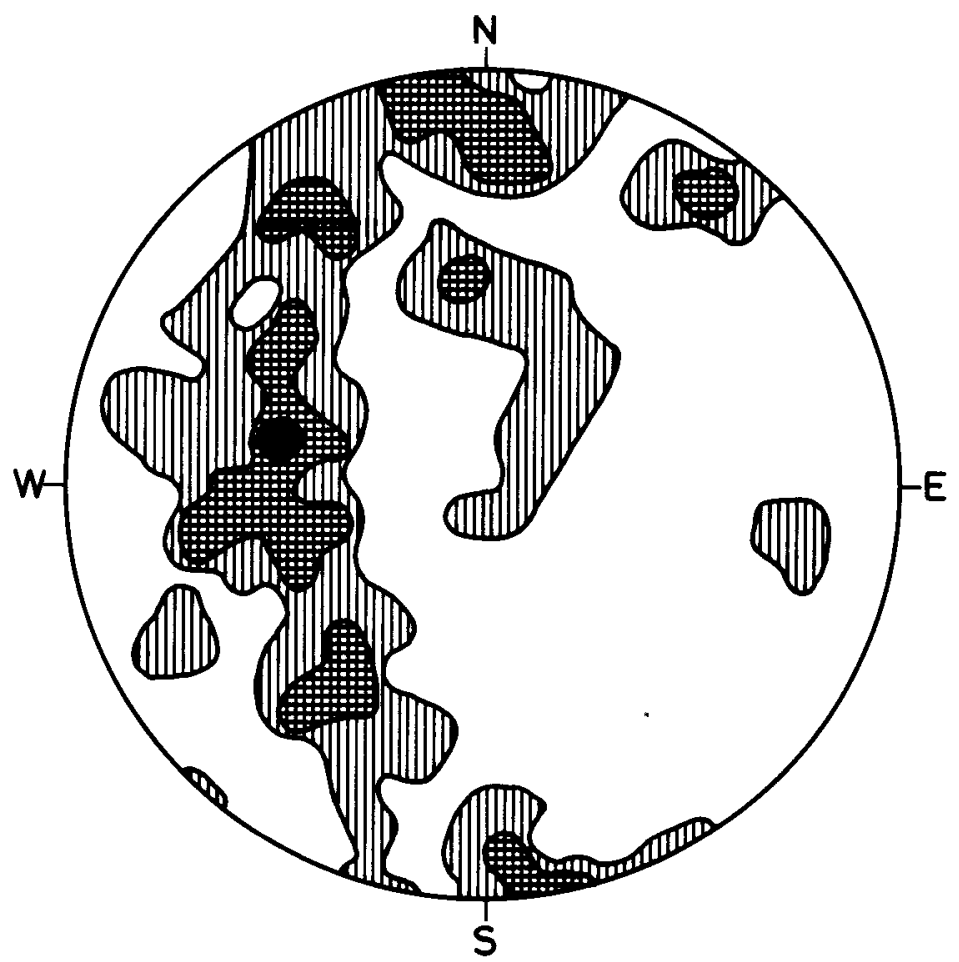

Fig. 4. Sønderskov south, lowermost till unit, a-fabric indicating ice movement from NW-SE.

\subsection{Late Pleistocene deposits}

The Late Pleistocene till and meltwater units are all referred to the Late Middle Weichselian and are mappable in the field.

The mapping has resulted in a clear division of the map sheet into two main areas, each with a different sedimentary succession deposited by an ice sheet or stream, each possessing a characteristic pattern and direction of movement, i.e. two kineto-stratigraphic drift units (Berthelsen 1973, 1978; Rasmussen 1975). The lithological mapping combined with the morphology and the study of glacial striae on boulder pavements, till-fabric analyses and the structural analyses of glacially induced deformations have helped to distinguish between drift units deposited by successive glacial advances coming from different directions. 

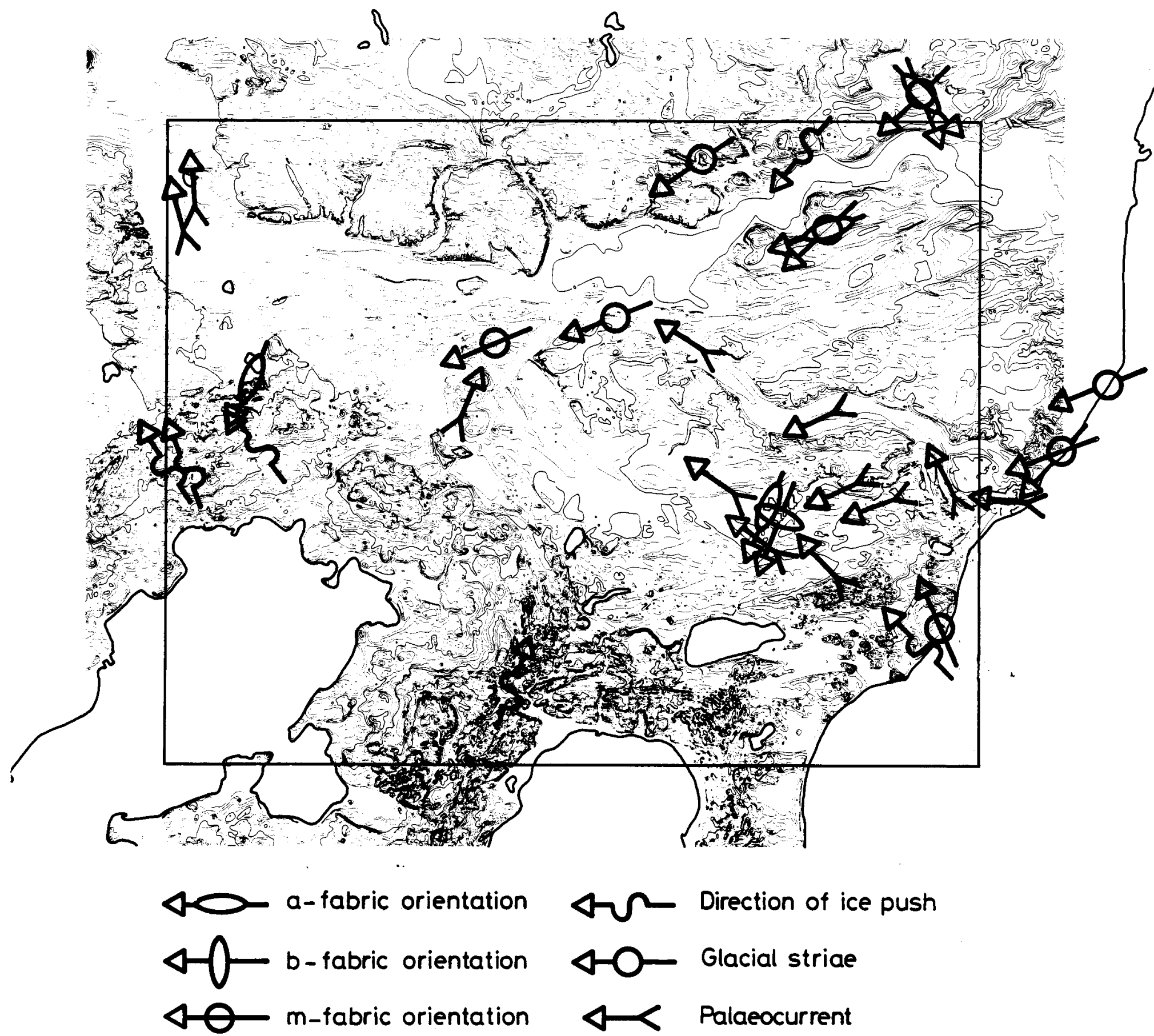

Fig. 5. Indications of fabric, ice push, striae and palaeocurrent measurements on the map sheet and surrounding areas. Reproduced with the permission of the Geodetic Institute (A.881/71). 
The oldest kineto-stratigraphic drift unit is situated north of a line running through the central part of the map sheet from Mørke, Thorsager, Ebdrup, Mårup and Tirstrup in the west to Balle in the east. This Pleistocene landscape was formed during an ice advance from east-northeast to west-southwest. This ice advance reached the Main Stationary Line. The oldest unit is represented by a ground moraine landscape to the northeast, a push-moraine landscape with parallel moraine ridges with a northwest-southeastern extension to the northwest, and a central and eastern area composed of elongated hills with a distribution in rows parallel to their elongation, a so-called drumlin landscape ( $\mathrm{fig}$. 2). This landscape is divided by broad east-west running valley systems filled up with outwash-plain sediments and Holocene deposits.

The youngest drift unit is situated south of the above-mentioned older drift unit and was formed during an ice advance from the south reaching the East Jutlandic Border Zone (Harder 1908). This advance has partly dislocated the Paleocene and Eocene clay, the Middle Pleistocene deposits and the Late Pleistocene sediments referred to the kineto-stratigraphic drift unit belonging to the ice advance from the northeast, and sediments deposited in front of the advancing ice lobes. These dislocations form the imposing concentric ridges bordering the two bays of $\mathrm{Kal} \varnothing \mathrm{Vig}$ and Ebeltoft Vig and the landscape further east at Rugard. North of these push-moraine ridges the sediments from the wasting ice have formed the sandur plains built up of extramarginal deposits of sand and gravel, the Tirstrup sandur and the Hoed $\AA$ outwash sediments. As mentioned earlier these meltwater streams intersected the older drift unit in the north.

\subsubsection{NE kineto-stratigraphic drift unit}

The easternmost observation where the drift unit from east can be established is the coastal cliff profile at Havknude. The fabric diagram (fig. 6) from the youngest till unit at Havknude shows long-axes lying in or close to a plane, which intersects the lower hemisphere in a great circle. The diagram shows in 


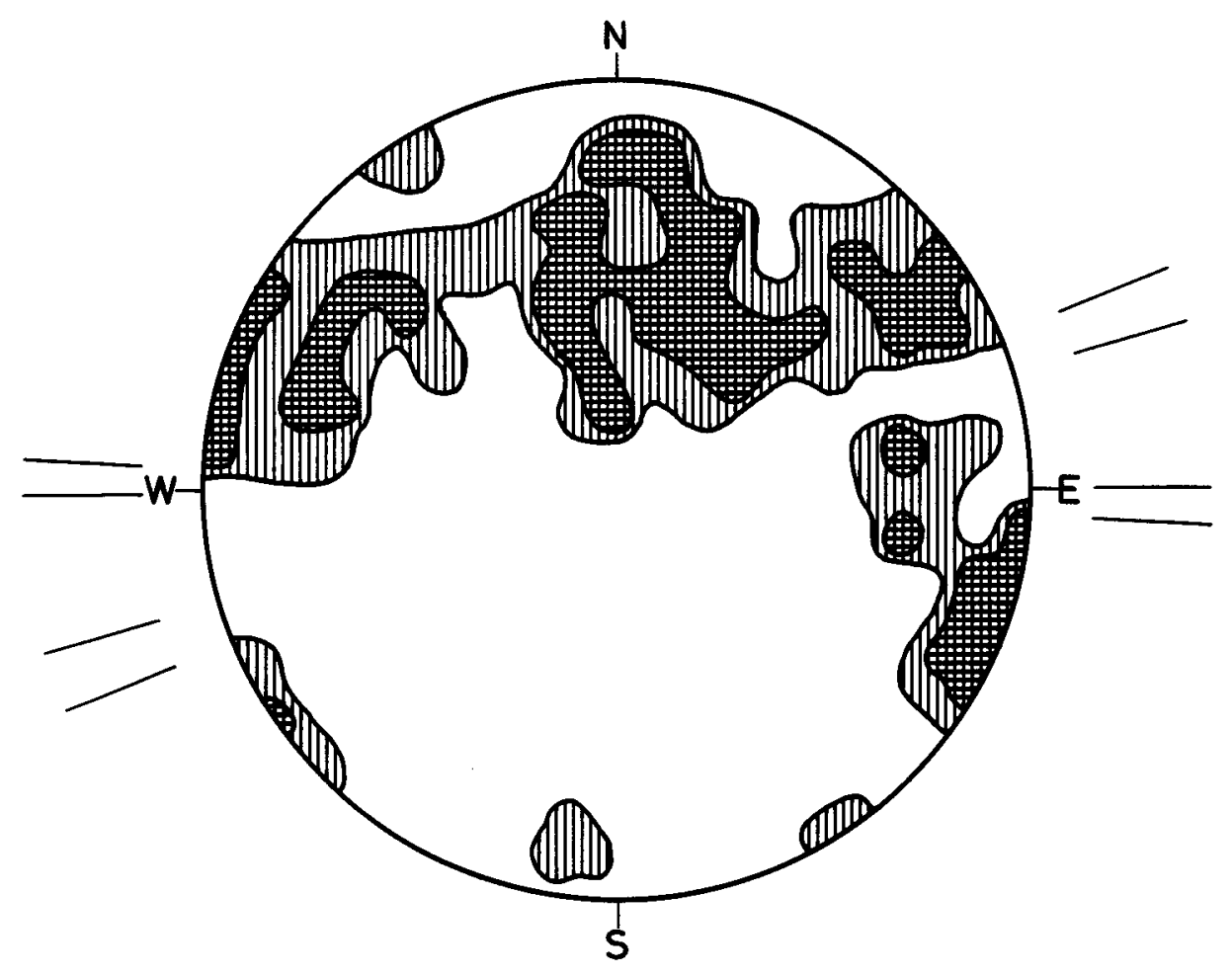

Fig. 6. Havknude, NE-drift unit, m-fabric and striae ENE-SSW.

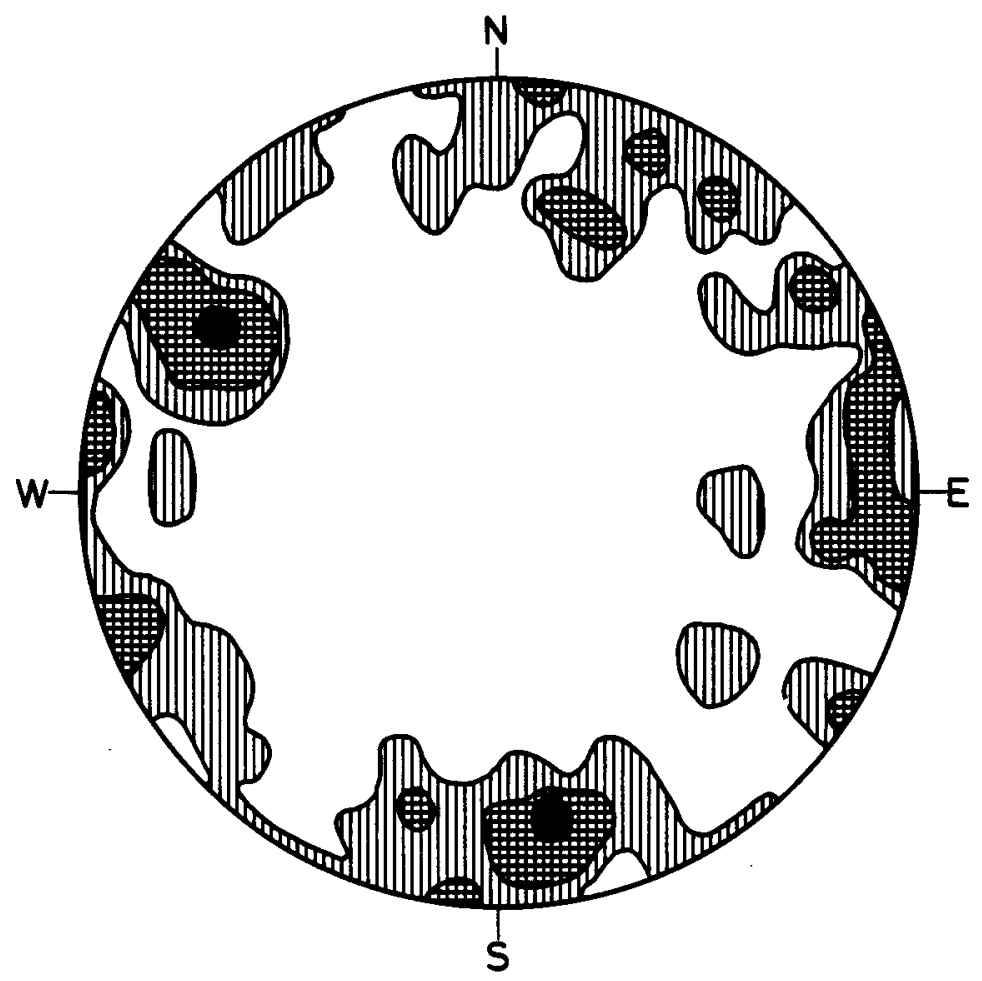

Fig. 7. Havknude south, NE-drift unit, ice movement from NE-SW. 
accordance with Nielsen (1981) an ice movement from east to west or from west to east. Glacial striae on glacial pavements in the same unit indicate an ice movement east-northeast to west-southwest or west-southwest to east-northeast. These observations are interpreted as evidence of an ice movement from northeast to southwest.

South of Havknude the coastal cliff shows a section of sandy till. The diagram (fig. 7) shows a rather inconsistent configuration with two pronounced maxima, one in the west-northwestern and one in the southern direction. The configuration indicates an ice movement from northeast to southwest.

The Kirial gravel pit is situated north of Enslev, a town in the extreme northeastern part of the map sheet. Stratified sand and gravel are here overlain by an at least $6 \mathrm{~m}$ thick till sequence. The fabric analyses have been carried out in the lower part of the sequence. The fabric diagram (fig. 8) is somewhat inconsistent. The projection shows four maxima, a northwestern, an east-southeastern, a north-northeastern and a south-southwestern. The northwestern maximum is the most pronounced. The diagram can be read as an a-fabric with a plunge in the northwestern direction, or as an m-fabric with two maxima, one in the northwestern and one in the east-southeastern direction. In order to interpret the diagram, directions of glacial striae on glacial pavements were measured. The measurements in the lower part of the till sequence show a northwest-southeast lineation and in the upper part a northeast-southwest lineation. The information obtained may lead to the demonstration of an ice advance from northwest to southeast gradually succeeded by an advance from northeast to southwest.

A small section through stratified sand and gravel is situated at Bloksbjerg, northwest of Ginnerup. The stratified drift is folded by ice pressure, and the fold-axis direction indicates an ice movement from northeast to southwest. 


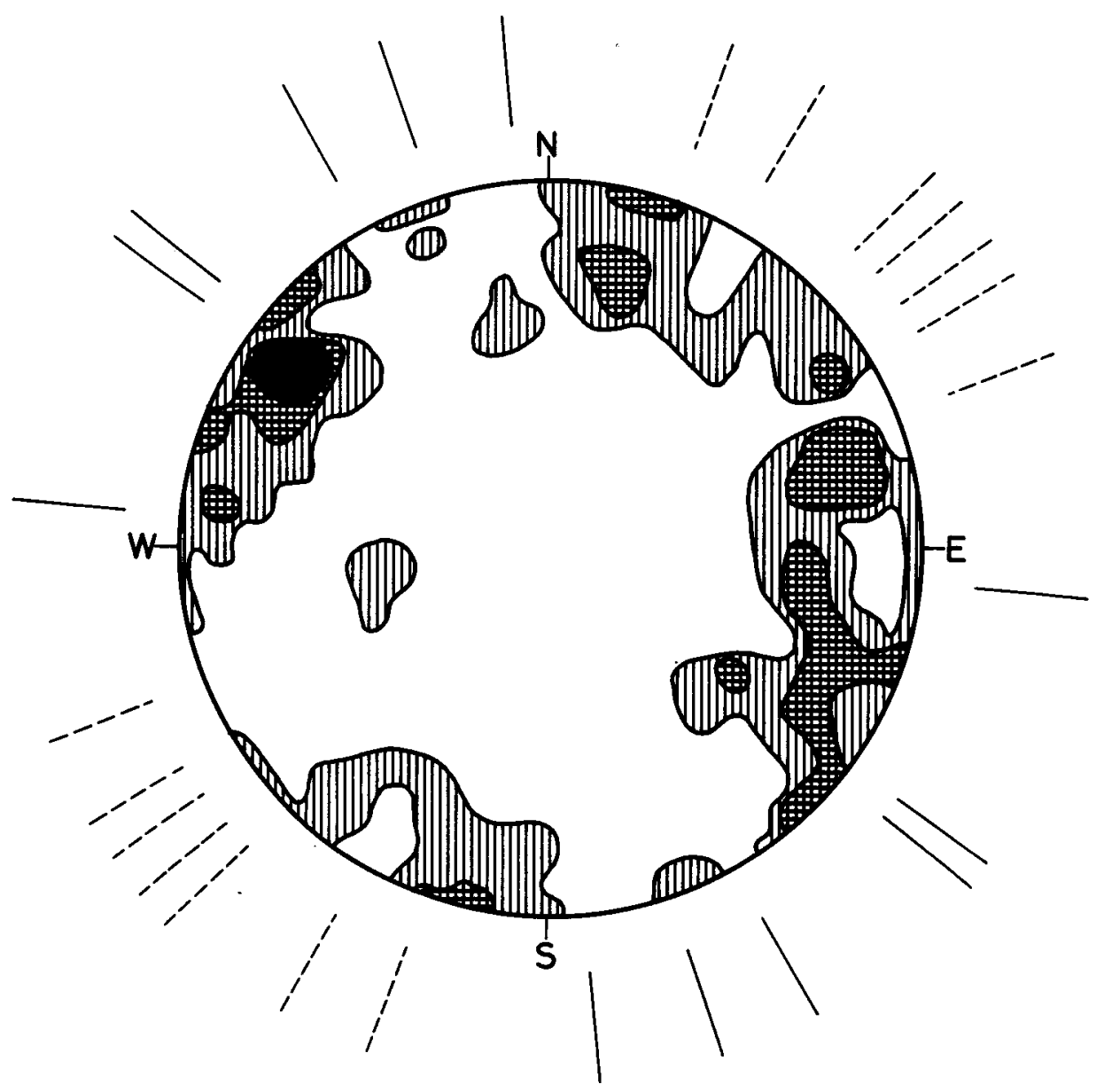

Fig. 8. Kirial. Fabric diagram from the lower part of the till unit with glacial striae NW-SE. Upper till unit with glacial striae NE-SW.

A gravel pit north of Skiffard shows an outwash delta exposed in a section. The material consists of sand and gravel. The meltwater sediments are underlain by a sandy till unit. Fabric analyses suggested an a-fabric representing an ice movement from northeast to southwest.

The mapping has disclosed a special pattern in the distribution of sediments in the Fjeld Skov area. Ridges of gravelly till and sandy till alternating with meltwater sand and gravel with a northwest-southeast trend indicate that the sediments were dislocated into floes by an ice push from northeast.

In the eastern part of the map sheet ( $3.3(p .13))$ elongated hills trending northeast-southwest occur as shown by Bahnson (1984). Investigation wells have proved a core very similar. to the core of the drumlins observed by Krüger \& Thomsen (1984). The hills, clearly showing the shape of a typical drumlin, are 


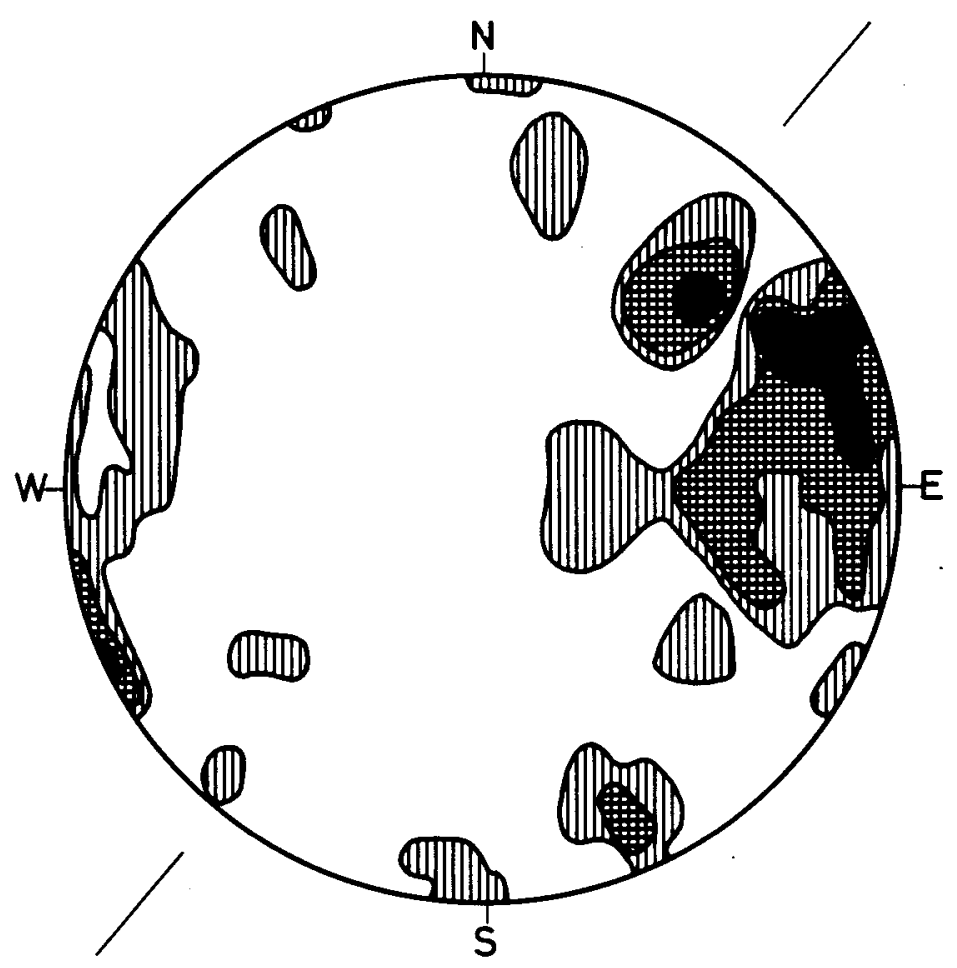

Fig. 9. Allelev, NE-drift unit, a-fabric, ice movement from ENE-WSW.

resting on the undulating Prequaternary limestone surface. Remnants of a till is resting on the limestone (The Middle Pleistocene till?). This till is overlain by more than $20 \mathrm{~m}$ stratified sand with elements of laminated clay and gravel. The core is mantled by a lime lodgement till. In accordance with the genesis of the landscape described by Krüger \& Thomsen (1984), the drumlin field on Djursland was built up as a meltwater deposit, later overridden by an ice sheet. The present shape of the drumlin has been caused by subglacial lodgement processes. The ice movement was from east-northeast to west-southwest. Fabric analyses have been carried out in the Bavnehøj drumlin near Allelev. The diagram (fig. 9) from the lime till, covering the distal part of the drumlin, shows an a-fabric with a plunge in the east-northeastern direction indicating an ice movement from east-northeast to west-southwest. Orientation measurements of glacial striae on glacial pavements confirm this interpretation. 
The locality of Skolleseng, north of Kelstrup, shows a profile in lime till. A fabric diagram (fig. 10) from the till section is placed in the northern slope of the drumlin-shaped hill. The projection shows a fabric very inconsistent but obviously of mixed type (m-fabric) with four maxima. The interpretation of the diagram is complex, but measurements of the directions of glacial striae on glacial pavements have an east-northeast west-southwest trend, parallel with the long axis of the elongated hill.

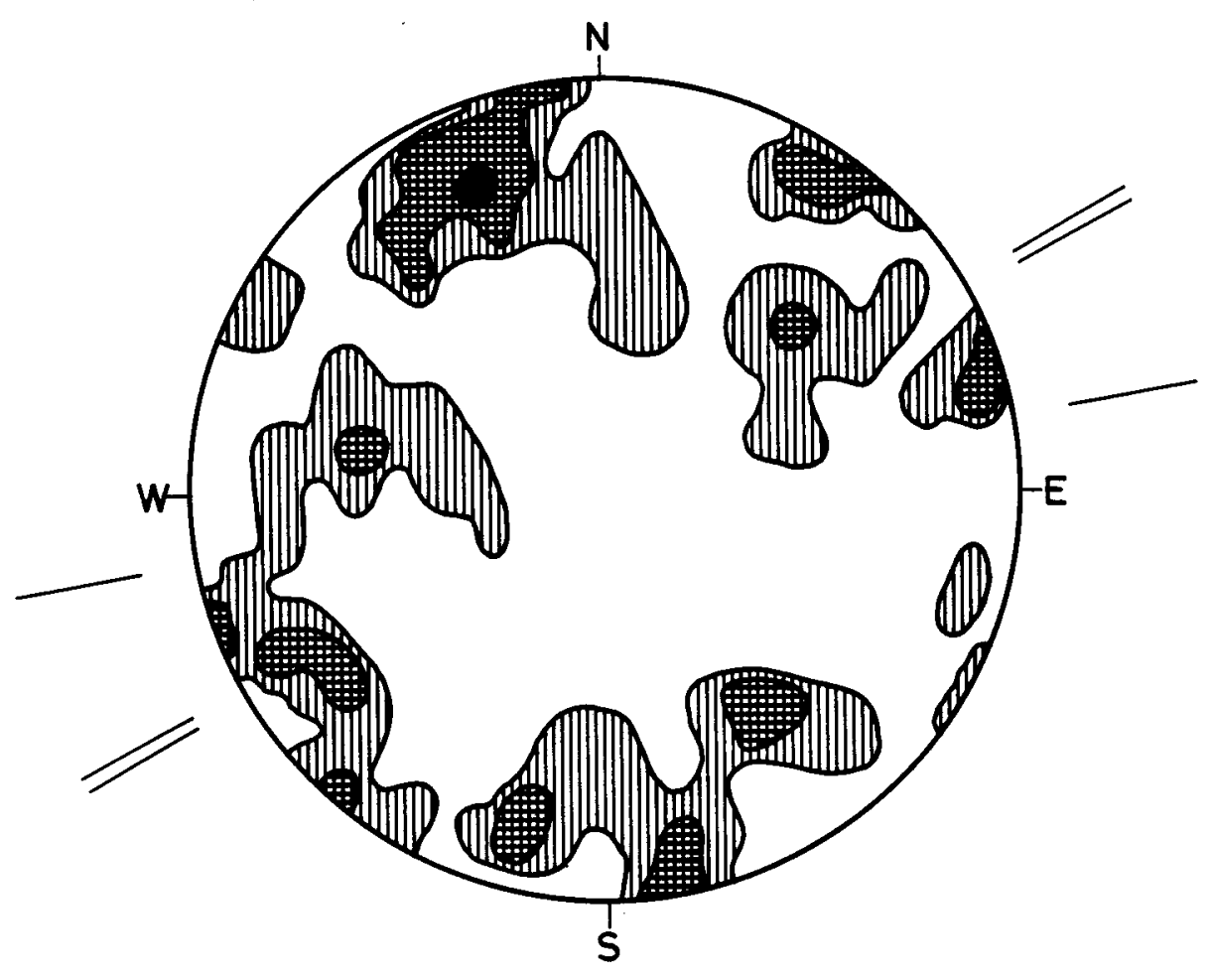

Fig. 10. Kelstrup, m-fabric together with striae. Ice movement from ENE-WSW.

The Bugtrup gravel pit near Ebdrup exposes a sandy till. The fabric diagram ( $f i g .11$ ) shows a mixed fabric (m-fabric) with a pronounced maximum in the east-northeastern direction and two minor maxima, one in the north-northeastern and the other in the south-southwestern direction. The configuration indicates an ice movement from east-northeast to west-southwest.

The gravel pit Visbjerg is situated between Mørke and Thorsager. The till unit is unconformably situated on a 
meltwater sand and gravel deposit, showing palaeocurrent towards the north. The till is the uppermost unit observed in the section. The diagram (fig. 12) shows an a-fabric with plunge in the north-northeastern direction. The 1ce-movement direction was consequently from north-northeast to south-southwest.

A characteristic pattern and direction of movement induced by an ice sheet from northeast can be demonstrated in the northern and central parts of the map sheet. Furthermore it can be

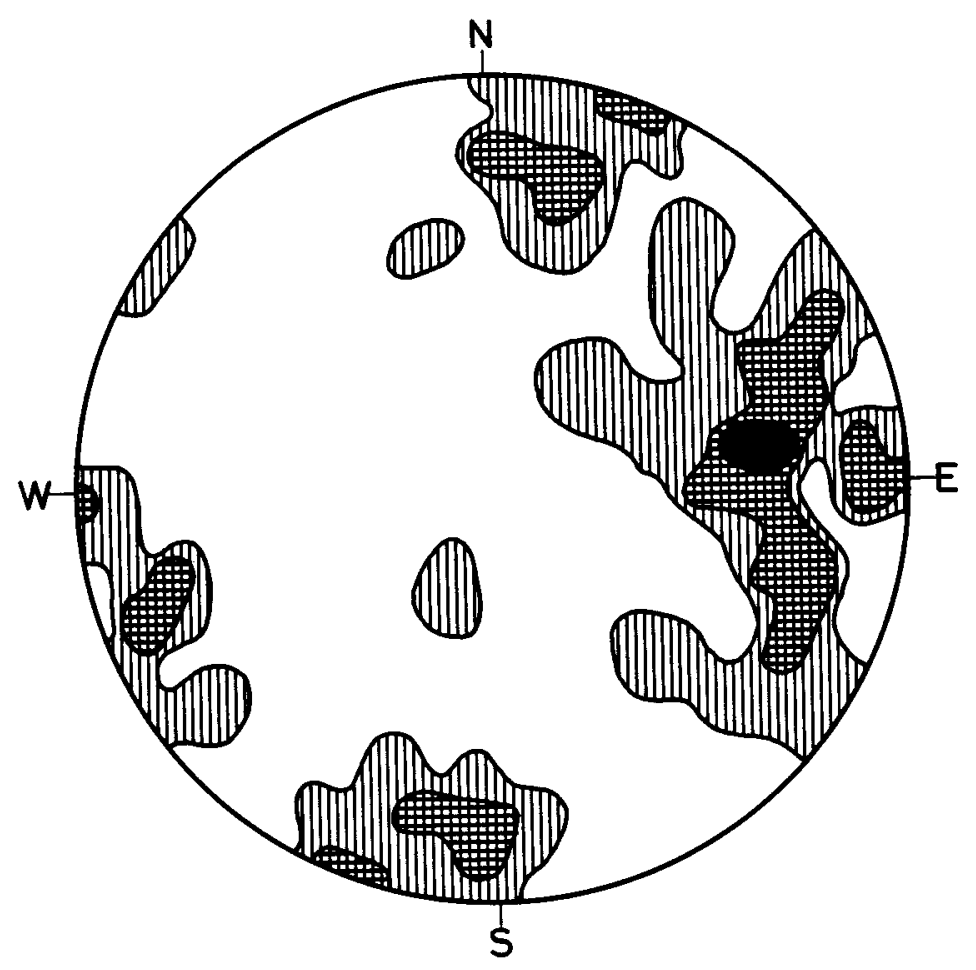

Fig. 11. Ebdrup, m-fabric, ice movement from ENE-SSW.

followed underneath the Tirstrup sandur belonging to a younger kineto-stratigraphic drift unit. This can be seen in two gravel pits situated on the Tirstrup sandur and at a maximum interval of $1 \mathrm{~km}$.

The profiles suggest a lower unit consisting of fine homogeneous sand without primary sedimentary structures which is overlain by more than $6 \mathrm{~m}$ sand and gravel showing trough cross-bedding. This upper unit rests unconformably on the 


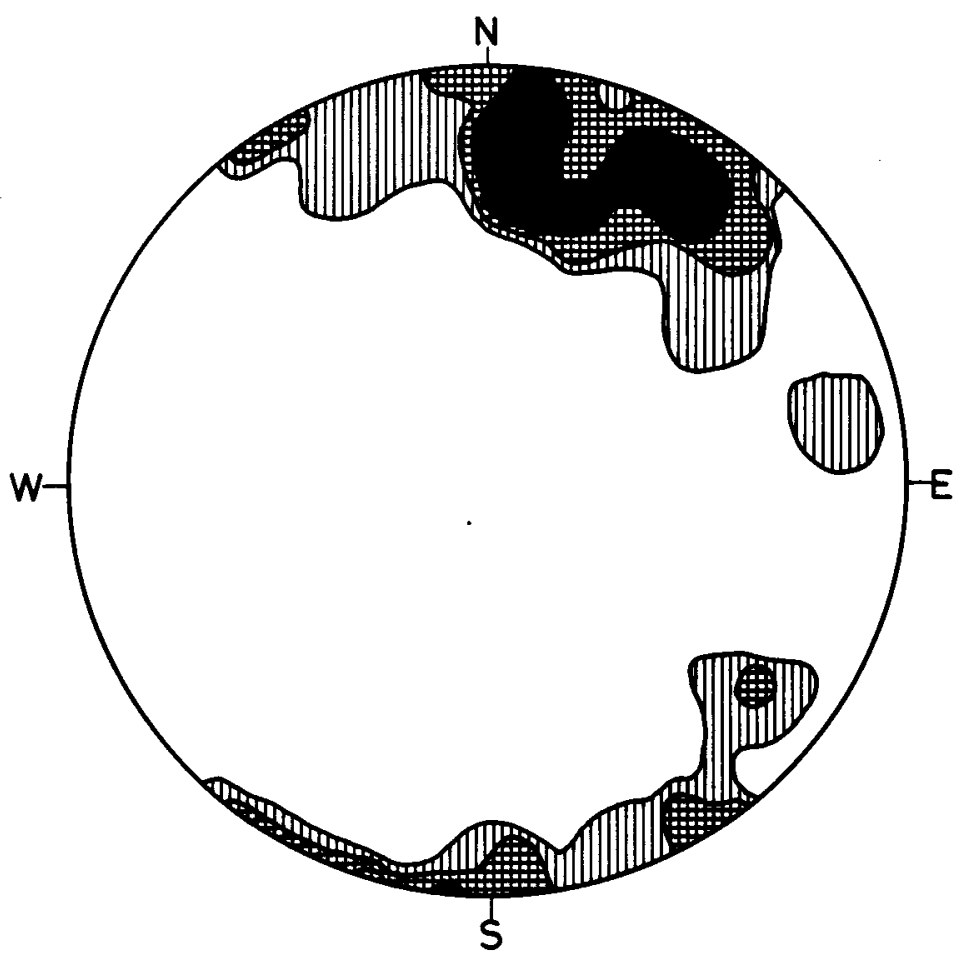

Fig. 12. Visbjerg, a-fabric, ice movement from NNE-SSW.

homogeneous sand. However, in between these units remnants of a till unit are found at both localities. The fabric diagram (fig. 13) from the till in the southernmost gravel pit shows two maxima, one in the east-southeastern direction and the other in the west-northwestern direction. The diagram shows a b-fabric indicating an ice movement from north-northeast to south-southwest or a reverse movement.

The northernmost gravel pit shows a till-fabric diagram (fig. 14) from the same stratigraphical unit. The projection shows a somewhat inconsistent picture but with a maximum in the north-northeastern direction (a-fabric). A comparison between the diagrams from the two gravel pits indicates an ice movement from north-northeast to south-southwest.

Considering the dynamic observations described above, the oldest Weichselian kineto-stratigraphic drift unit consists of deposits laid down by an ice sheet moving from northeast to southwest. It is found in the northern and central parts of the map sheet (see table 1). However, this landscape has a certain 


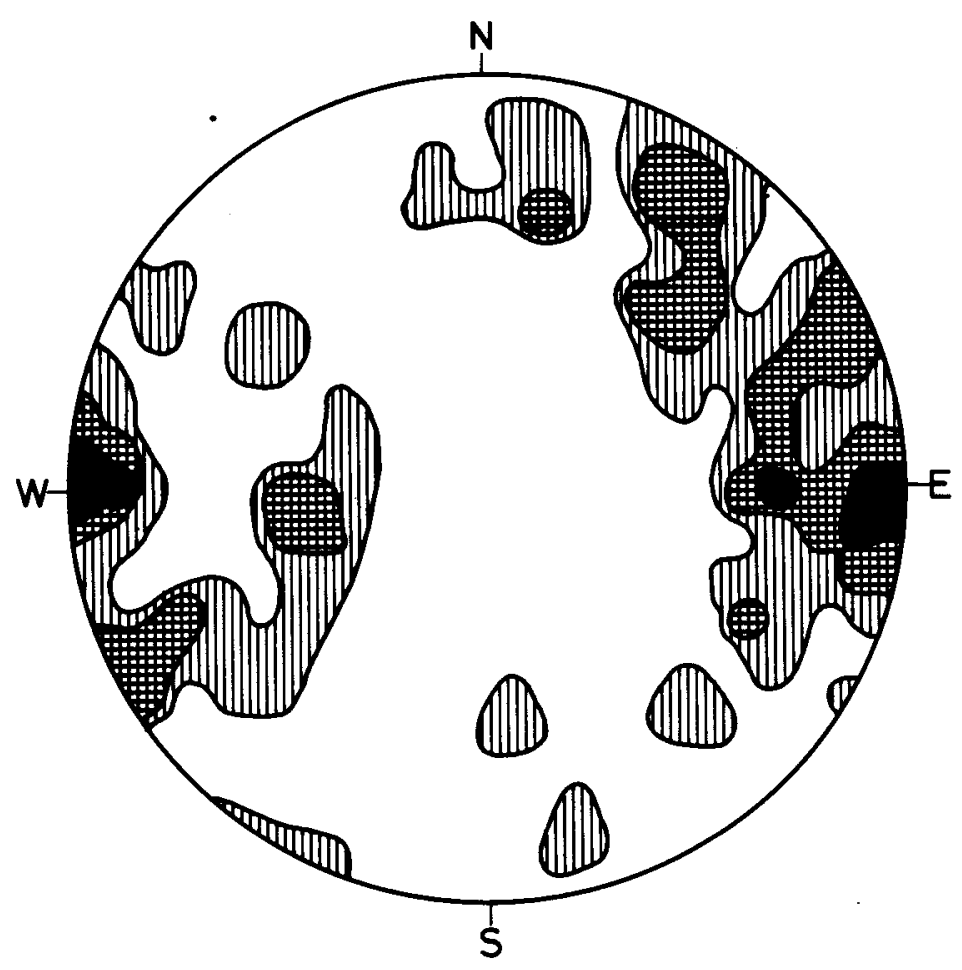

Fig. 13. Tirstrup south, b-fabric, ice movement NNE-SSW.

differentiated spatial position of sediments in the various regions. In the northeastern part of the map sheet, north of Kolindsund, meltwater sand and gravel are overlain by sandy and gravelly till. In the northwestern part of the map sheet, the Fjeld Skov area, these sediments are dislocated from northeast. In the central part, between Kolind and Tirstrup, layers of meltwater sand are overlain by sandy and clayey till. The drumlins in the eastern part are built up of meltwater sand and clay with a mantle of lime till as mentioned above. In the area south of Trustrup the surface mapping has demonstrated a more than $20 \mathrm{~m}$ thick formation of meltwater clay overlain by meltwater sand covered by clayey till. The present field work has not arrived at a recognition of a Norwegian glaciation as pointed out by Bahnson (1984).

\subsubsection{S kineto-stratigraphic drift unit}

North of Nørres $\varnothing$ in the Tyknet Skov at Rugard the easternmost section of the southern kineto-stratigraphic drift unit is 


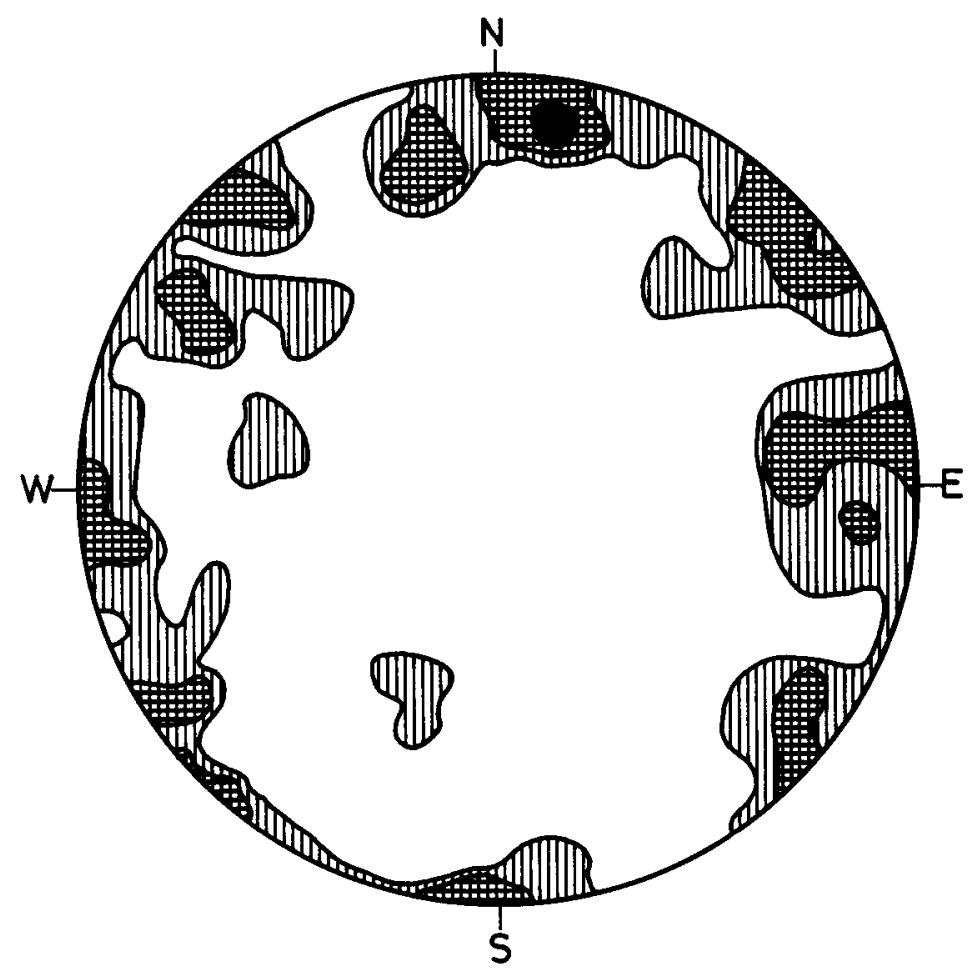

Fig. 14. Tirstrup north, a-fabric, maximum into NNE. Combined with fig. 13 they show an ice movement from NNE-SSW.

found. The diagram (fig. 15) from the top of the section in the sandy till has two maxima, one in the northeastern and one in the southwestern direction, and it is believed to represent a b-fabric. The ice-movement direction is consequently estimated to be from southeast to northwest or from northeast to southeast. However, the northeastern maximum is the most pronounced, and therefore the diagram is not unequivocal. It is consequently not recorded on fig. 5 .

The coastal profile south of Sønderskov in the Rugard area contains a sequence which represents the Middle Pleistocene deposits mentioned in chapter 6.1 ( $p .30)$. The whole sequence was dislocated by an ice movement from the south.

Dipping beds of clay can be observed at Jernhatten. This Prequaternary deposit was transported and dislocated by an ice pressure from the south. 


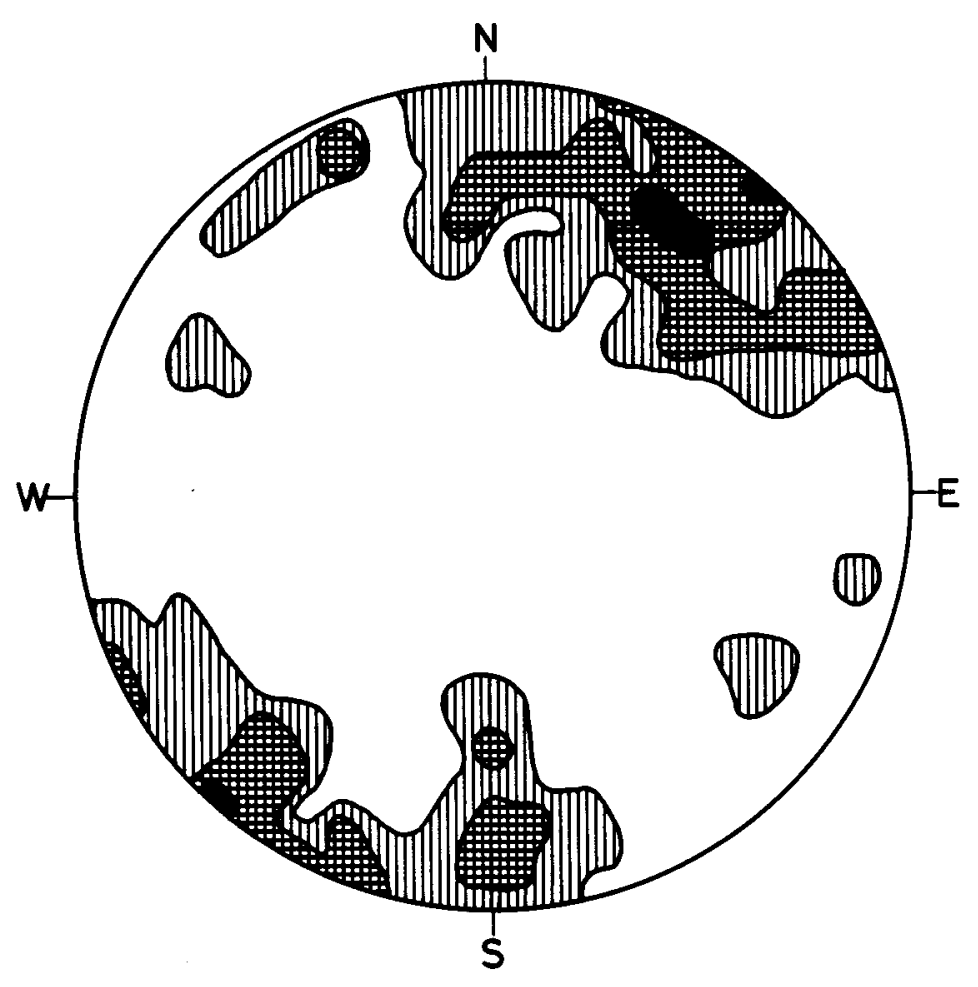

Fig. 15. Rugård, S-drift unit, b-fabric. An estimated ice movement from $\mathrm{SE}-\mathrm{NW}$ or $\mathrm{NW}-\mathrm{SE}$.

and sandy till dislocated by ice pressure from the south. A sandy till unit is placed unconformably on these structures. In connection with the construction work of a highway between Løgten and Tåstrup, at Trehøje, it has been possible to study sections of dislocated strata and to carry out tectonic analyses. West of Ugelbølle in the western part of the map sheet ice pushes have been measured at two localities. Both showed an ice movement from south-southeast to north-northwest. Ice pressure from southeast to northwest is also demonstrated west of Følle (see fig. 5).

The youngest kineto-stratigraphic drift unit consequently belongs to an ice coming from the south. This ice has dislocated and created the curved moraine ridges bordering the Kalø Vig and Ebeltoft Vig and has formed the complex of hills from Skærs $\varnothing$ Plantage to Hyllested Bjerge. The moraines can be followed out into the Kattegat (Larsen \& Knudsen 1983). The ridges are built up of floes of Paleogene clay, Middle and Late Middle Pleistocene deposits and meltwater depositions in front 
of the advancing ice lobes from the south. The maximum extension of this drift unit from the south is found from Mørke, Thorsager, Rostved, Feldballe, and south of the Tirstrup Hedeslette (sandur) to a position near Glatved in the east. The kineto-stratigraphic drift unit from the south overprints the older kineto-stratigraphic drift unit from the northeast. The position of the southern ice just south of Tirstrup sandur is elucidated by the high-lying outwash plain of Tirstrup contrasting the area towards the south by a difference in level of approximately $10 \mathrm{~m}$.

The flow of the meltwater from the wasting ice sheet has been followed in a series of measurements of palaeocurrents in gravel pits. First the transportation of sediments was from Glatved over Tirstrup Hedeslette through the valley south and west of Kolind towards Pindstrup and Kastrup Mose, secondly a younger drainage system is found in the valley of Hoed $\AA$ and its continuation skoda at a level of about $20 \mathrm{~m}$. There is no evidence of outwash sediments north of Karby. It is plausible that the meltwater followed the Kolindsund to the east at a later stage, but it is pure speculation based on the occurrences of higher-lying terraces west of Kærby, as mentioned in chapter $5.3(p .23)$.

\subsection{The Holocene history}

The stratigraphic and spatial positions of the Holocene sediments accumulated within the Rønde map sheet area show no marked change from the Late Weichselian to the Holocene. However, it must be stressed that during Late Weichselian (from 13,000 BP - Mangerud et al. 1974) and up to Early Holocene the area was deeply eroded due to the low-lying erosional base during the continental period. During this period most of the Danish area, including part of the present sea territory, was above sea level (Petersen 1985a fig. 7) and consequently the deeply cut part of the Kolindsund is regarded as having been formed during this period as is also the case of the indentations in the northern levelled part of the map sheet. 
At the Fugls $\varnothing$ depression north of the Rønde map sheet a lake existed as early as in the Late Weichselian. This lake became a mire about 8000 BP (Aaby 1986). In the Kolindsund area peat is also found below the marine deposits from the transgression which took place during the Atlantic (from 8000 BP).

The history of the lake/fjord system Korups $\varnothing$ can be dated back to the Boreal (by pollen analyses - H. Krog pers. comm.). Freshwater deposits with Anodonta and other lacustrine molluscs are found underlying the beds from the marine transgression during the Atlantic. The marine stage existed up to Late Subboreal according to $\mathrm{C}-14$ dating of the brackish water species (Cardium lamarchi) from the area. Subsequently freshwater gyttja was deposited until the lake was reclaimed in the last century.

The deposition of younger freshwater gyttja and sand follows within the whole area partly covering part of the marine strata in the old fjord system (see 5.1 .4 (p.21) and 5.4 (p. 26 )). For a stretch of $18 \mathrm{~km}$ west of Grena the Kolindsund remained a lake up until 1872 when that area was reclaimed as well (Andersen 1938).

The history of forests on Djursland (Andersen 1984) provide us with data on the highly varying time for soil formation in the terrestrial environment. It appears that it is partly depending on the type of soil and partly on the periods with cultural influences (op.cit. p. 166).

\subsubsection{Freshwater and peat deposits}

The older lacustrine deposits do not appear on the drift map as they are concealed by the younger deposits. However, pollen spectra from the Late Weichselian Allerød Chronozone showed that lakes existed then and throughout the entire Holocene (Andersen 1984). It has not been possible to date the age of the formation of the lake and stream systems (chapter 3.2 ( $p$. 12)) which have mainly been formed in a dead-ice complex. 
An uninterrupted formation of freshwater gyttja (FP) must have taken place in the hilly southern part and in the western part of the levelled northern region with crescentic hills.

The later formation of gyttja within the stream and lake systems took place in Late Subboreal and Subatlantic. Peat deposits (FT) represent the final and youngest event and have covered extensive areas in the northwestern part of the stream and lake systems (Kastrup Mose and Pindstrup Mose, see chapter $3.2(p .12$ )). These areas have been exploited commercially.

\subsubsection{The Littorina fjord stages}

The deposition during the Littorina sea period is elucidated by the investigations of the Korups $\varnothing$ area carried out on the basis of diatoms, pollen and Hystrix analyses (Iversen 1937). Recently the work on microfossils has been reassumed and combined with studies on macrofossils, especially molluscs. This supplies us with information on the environmental changes through time and with absolute ages of shell material using C-14 analyses.

The oldest recorded stratum in Korups $\phi$ is a lacustrine Boreal lime gyttja (FP) which in Early Atlantic was covered by saltwater gyttja (HP) with a rich fauna of molluscs. The fauna is characterized by the bivalves Ostrea edulis, Venerupis sp., Macoma balthica and Corbula gibba.

The gastropod Bittium reticulatum is only found in large quantities within this older part of the sequence up to the end of the Atlantic. The disappearance of Bittium reticulatum in the Subboreal is explained as having been caused by a change to a more brackish environment. This explanation is supported by the decline in numbers of Hydrobia ulvae and the occurrence in equal number of Hydrobia stagnorum which characterizes the brackish water.

The rate of sedimentation was low during the Atlantic ( $2 \mathrm{~m}$ per thousand years) compared to the Subboreal, when a sedimentation of up to $8 \mathrm{~m}$ per thousand years during part of the subboreal is 
found in the centre of Korups $\phi$.

In the eastern part of Kolindsund the youngest marine deposits of gyttja (HP) belong to the Early Subatlantic, when the formation of beach ridges along the Kattegat coast closed the fjord system. This general trend was supported by the isostatic uplift as mentioned in chapter 5.2 .2 ( $p .22$ ). 


\section{CONCLUSIVE REMARKS}

The region described above constitutes only a part of the area which was surveyed during the Vulnerability Project. However, the main regions and sedimentary units established during the geological mapping can be regarded as being representatives of the various deposits dealt with in the region of the Vulnerability Project on Djursland.

Furthermore, the succession of events has been elucidated by using the kineto-stratigraphic drift units in the pleistocene strata and the study of the ordinary succession of strata in the Holocene. The spatial position of the Pleistocene and Holocene units is given on table 1.

The oldest Pleistocene unit has been observed in cliff exposures and in wells. The position of the unit is indicated on the cross-section of table 1 , and it occurs on the Prequaternary surface as erosional remnants.

The Middle Weichselian drift unit from the northeast is featured on the northern and central eastern parts of the map sheet, locally occurring as lime till. This drift unit is composed of a lower sequence of meltwater sand and clay, recognized in several wells and cropping out in the ravines as depicted in the cross-section (see table 1). The unit is found under-lying the outwash sediments of Late Middle Weichselian age, and to the south it is dislocated by the youngest drift unit. The drift unit from the south contains floes of paleogene material, dislocated strata of a till unit from the northeast, and boulders forming the moraines in the southern part of the map. The kineto-stratigraphic point of view is here restrained by the measurements of dislocated strata in the ice-push zones within the East Jutlandic Border Zone (fig. 5). The configuration of this zone follows the outline of the southern 
drift unit from the south occurs in the southern part within the region of Upper Paleocene clay and marl.

The northernmost part of the drift unit from the south mainly consists of sandy deposits in an area with kettle holes. The high-lying part of the sandur at Tirstrup has been sustained by the ice margin from the south.

The outwash sediments can be followed across the map, and as seen from the cross-section (table 1) it runs at different levels in the eastern part, reflecting older and younger stages of terraces. The thickness of these strata is rather small, and windows of the drift unit from the northeast occur. Furthermore remnants of the oldest Pleistocene unit is found in wells south of the map sheet.

The Holocene strata fill in the areas with enclosed hollows such as the lake area in the crescentic hills and kettle holes. Furthermore, the Holocene is found in the former marine areas and along the stream systems.

The thickness of these strata may vary greatly depending on whether the subsurface has been eroded through the ages with a low erosional basis or whether it occurs within the zone with kettle holes of varying depths. The strata mainly consist of gyttja - both of marine and freshwater origin. 


\section{ACKNOWLEDGEMENTS}

The authors direct their sincere thanks to the Geological Museum of Copenhagen for the permission to use the late Dr. H. Wienberg Rasmussen's mapping of Mols Bjerge.

The field work was carried out with the assistance of the following students from the University of Copenhagen: cand.scient. Ole Bennike, stud.scient. Anne Brehmer, stud.scient. Gregers Dam, stud.scient. Bent Kjær Hansen, cand.scient. Jørn Bo Jensen, cand.scient. Lars Nydahl Jørgensen, and from the University of Aarhus: cand.scient. Kurt Jakobsen, cand.scient. Gitte Bruun Jørgensen, stud.scient. Niels Peter Mortensen and cand.scient. Søren Nielsen. The authors express their appreciation of this assistance.

The authors want to thank S. Th. Andersen, H. Krog and B. Aaby from the Division for Geobotany of the Survey for information on the Holocene strata. Furthermore we express our gratitude to H. Bahnson who carried out the laboratory work, T. F. Jensen who made the drawings, and to Birgit Jørgensen who corrected the English and typed the book. 


\section{DANSK SAMMENDRAG}

Den geologiske kortlægning af kortbladet 1315 II Rønde blev genoptaget $i$ 1981. På dette tidspunkt forelå dog et mindre område publiceret, nemlig den sydige centrale del af kortbladet omfattende Mols bjerge (Rasmussen 1977). Kolindsund er kortlagt under ledelse af A. Jessen 1936. Desuden har der $i$ perioden 1968-1977 været udført kartering under ledelse af H. Bahnson. På det vedlagte jordbundskort indgár herfra karteringen af Fjeld skov. Afgrænsningen af de geologiske kortblade følger Geodætisk Instituts rammer for 1:50.000 kortene. Karteringen udf $\phi r e s$ pá basis af G.I.'s 1:25.000 kort. Første udtegning foreligger som de geologiske jordartskort 1:25.000 og udkom sommeren 1985. Det endelige kort $i$ sort-hvid udgave 1:50.000 var udarbejdet efteråret 1985, og den medf $\phi$ lgende rapport forelå januar 1986 .

Den sydlige del af kortbladet omkring Ebeltoft Vig og Kal $\varnothing$ Vig er karakteriseret af en stor variation $i$ jordarternes sammensætning, spændende fra fed moræneler og diluvialler over morænegrus til sand. I nogle partier forekommer de enkelte jordarter i hojderygge med mellemliggende tørvefyldte lavninger. Prækvartære bjergarter $i$ form af Paleocænt ler og Rфsnæsler, alternerende med istidsaflejringer, optræder som flager, der er opskudt fra undergrunden ved istungernes pres fra syd. Isloberne har derved skabt de to viges form.

Randzonen for dette yngste isfremstød har ikke ligget fast, men oscilleret over en flere $\mathrm{km}$ bred front. Under dette hændelsesforløb er der udformet et dødislandskab, karakteriseret ved tilstedeværelsen af større og mindre dødishuller i sand og med stedvis større blokke og grus, medens lerede bjergarter ikke forekommer $i$ overfladenære lag. Uregelmæssige tørveholdige lavninger kan vidne om rester af ældre afstrømningsfloder, hvis løb på grund af de sammensatte geologiske processer, som isafsmeltningen medførte, dog ikke kan erkendes $i$ dag. 
sandur (hedeslette), som ses opbygget i området $\emptyset$ st og vest for Tirstrup. Øst for Korups $\varnothing$ ses denne sandur at ligge omkring 15 meter højere end det ovenfor omtalte dødislandskab. Det viser, at isfronten på tidspunktet for hedeslettens dannelse stod som begrænsning ind mod Tirstrup hedeslette $\phi$ st for Korups $\phi$.

I Tirstrup hedeslette er sand og grus enerådende. Når man stedvis konstaterer lerede aflejringer i denne flade, er det vidnesbyrd om det underliggende ældre glaciale landskab, der i vekslende dybde findes under det ekstramarginale sand og grus og stikker igennem som et geologisk vindue.

De ovenfor beskrevne landskabstyper, omtalt fra syd mod nord, repræsenterer en typisk "glacial serie" omkring en isfront, hvor denne har stået i længere tid. Landskabskomplekset indgår som del af den $\phi$ stjyske israndslinie. Dens dannelse henføres til slutningen af Weichsel nedisningen, og på basis af dateringen af en mammutst $\varnothing$ dtand indlejret i gruset i Tirstrup sandur, må opbygningen af dette afsmeltningskompleks være sket mellem 13.000 og $14.000 \mathrm{BP}$.

Den nordlige del af Røndebladet omfatter området nord for en linie forløbende fra Mørke, over Thorsager, Ebdrup, Mårup og Tirstrup til Balle i $\phi s t$. Kolindsund, der som en op til $2 \mathrm{~km}$ bred lavning gennemskærer Djursland i øst-vestlig retning, og andre større lavninger, som præger Djursland, sættes naturligst i forbindelse med afstrømningsforløbets erosive fase under afsmeltningsforløbet for den sydfra kommende ismasse. Dødiskomplekser tilhørende afsmeltningen indgår $i$ landskabets udformning omkring dannelsen af sandursletternes ældste dele, som $i$ omradet omkring Korups $\varnothing$ i den vestlige ende af Tirstrup sandur.

En ældre isstrømsbevægelse kan konstateres i området nord for Trustrup. Her er der udviklet drumlinoide bakkestrøg med en sydvest-nord $\phi$ stlig orientering. Her er den dækkende moræneenhed kraftigt præget af oparbejdet kalk (kalkmoræne).

Under denne dækkende kalkmoræne findes et glacialt lagkompleks bestående af smeltevandssilt og -ler, der kan følges over et 
større omràde strækkende sig fra Balle-Hoed området $i$ den $\varnothing$ stlige del i kortbladet til centralt ved Bjørnholm sydøst for Hallendrup. Dette forhold fremgår af karteringen sammenholdt med unders $\emptyset$ gelsesboringer, da sidste nedisningsfases ekstramarginale dannelser har eroderet dette udstrakte ler-silt-sand legeme, som træder frem $i$ Skodå-Hoed A dalen. Aflejringerne $i$ den nordiige del af kortbladet, afsat af et isfremstød fra nordøst til sydvest, anses for at repræsentere afsætninger under den maksimale isudbredelse $i$ Weichsel. Aldersmassigt henføres denne til omkring 20.000 før nu.

De glaciale dannelser inden for Røndebladet er af ung alder, idet de dominerende overfladenære sedimenter og isbevægelser inden for området er afsat og har virket inden for de sidste 20.000 år. Men jordlagenes sammensætning er stærkt afvigende i den nordiige og den sydlige del af området. I syd findes der starkt dislocerede $\mathrm{lag}$ af vekslende ler-sand-grus samt flager af Prækvartæret, medens man $i$ nord har udstrakte ikke dislocerede smeltevandsaflejringer, stedvis - særlig i den nordøstlige del - overlejret af den ovenfor omtalte kalkmoræne.

Det geologiske hændelsesforløb, som er beskrevet ovenfor, er fremkommet ved anvendelse af det kinetostratigrafiske princip (Berthelsen 1973, 1978). Aflejringer, der er knyttet til et bestemt isdækkes fremstød og afsmeltning, udgør en kinetostratigrafisk enhed, fordi deres aflejringsstrukturer og deformationsstrukturer er udviklet $i$ overensstemmelse med bevægelsesbilledet $i$ denne isstrøm. De geologiske data, som er anvendt til oprettelse af kinetostratigrafiske enheder på Røndebladet, har været stenorienteringsmålinger, målinger af skurestriber på glaciale brolægninger, analyser af glacialtektoniske deformationer og målinger af palæostrømretninger. De observerede dynamiske retningselementer er indtegnet på fig. 5. Disse underbygger antagelsen af en ældre kinetostratigrafisk enhed afsat af en is fra nordøst og en yngre kinetostratigrafisk enhed afsat af en is fra sydlig retning, svarende til de aldre og de yngre glaciale aflejringer beskrevet ovenfor. Den rumlige placering af de to enheder fremgår af tabel 1 .

I det hidtil omtalte er kun de euglaciale aflejringer og pro- 
cesser blevet nævnt. Fra Kolindsund strækker sig et større kompleks af lavtliggende områder, som i postglacialtid har været transgrederet af havet fra tidligt i Atlantikum til op mod Subatlantikum. Hvor vidtstrakt dette system er inden for Røndebladet kan anskueliggøres af, at ovennærnte Korups $\varnothing$ udgjorde det inderste $i$ det marine sund, der i Stenalderen strakte sig fra Randers Fjord til østkysten af Djursland. Endvidere finder man, at $\varnothing$ stkysten fra Rugård og sydover $i$ ældre tid har været stærkt fliget og med dybe indskæringer så langt som til Stubbe $S \varnothing$ i den sydøstlige del af kortbladet. Kortbladet Røndes orografiske konfiguration for 3000 år siden har således været meget afvigende fra dets nuværende udseende. 


\section{REFERENCES}

Andersen, S.A. 1938: Kolindsund i Litorinatiden. Naturhistorisk Tidende 2, pp. 25-26.

Andersen, S.Th. 1984: Forests at L $\varnothing$ venholm, Djursland, Denmark, at present and in the past. Biol. Skr. Dan. Vid. Selsk. $24: 1,208 \mathrm{p}$.

Bahnson, H. 1984: Lithological and Stratigraphical Investigations of Types of Till in Northern Djursland, Jutland, Denmark. Striae 20, pp. 21-26.

Berthelsen, A. 1973: Weichselian ice advances and drift successions in Denmark. Bull. Geol. Inst. Univ. Upps., New Ser. 5, pp. 21-29.

Berthelsen, A. 1978: The metodology of kineto-stratigraphy as applied to glacial geology. Bull. geol. Soc. Denmark 27, Special Issue, pp. 25-38.

Bornebusch, C.H. \& Milthers, K. 1935: Jordbundskort over Danmark (Soil Map of Denmark). Danm. geol. Unders. III. Rk., $24,68 \mathrm{p}$.

Dinesen, A., Michelsen, O. \& Lieberkind, K. 1977: A survey of the Paleocene and Eocene deposits of Jylland and Fyn. Danm. geol. Unders. Serie B, 1, $15 \mathrm{p}$.

Gry, H. 1935: Petrology of the Paleocene Sedimentary Rocks of Denmark. Danm. geol. Unders. II. Rk., 61, 171 p.

Grönwall, K.A. \& Harder, P. 1907: Paleocæn ved Rugaard i Jydland og dets Fauna. Danm. geol. Unders. II. Rk., 18, 102 p.

Hansen, H.J. \& Andersen, B.B. 1969: The occurrence of clinoptilolite-replaced foraminifera in the Danish Upper Selandian non-calcareous greensand. Bull. geol. Soc. Denmark 19, pp. 197-203.

Harder, P. 1908: En østjydsk Israndslinje og dens Indflydelse paa Vandløbene. Danm. geol. Unders. II. Rk., 19, 262 p. Heilmann-Clausen, C. 1982: The Paleocene-Eocene boundary in Denmark. Newsl. Stratigr. 11:2, pp. 55-63. 
Heilmann-Clausen, C. 1985: Dinoflagellate stratigraphy of the uppermost Danian to Ypresian in the Viborg 1 borehole, central Jylland, Denmark. Danm. geol. Unders. Serie A, 2, 69 p.

Iversen, J. 1937: Undersøgelser over Litorinatransgressioner i Danmark. (Foreløbig Meddelelse). Meddr fra Dansk Geol. Foren. 9, pp. 223-232.

Jessen, A. 1920: Stenalderhavets Udbredelse $i$ det nordlige Jylland. Danm. geol. Unders. II. Rk., 35, $112 \mathrm{p}$.

Kalsbeek, F. 1963: A hexagonal net for the counting-out and testing of fabric diagrams. N. Jb. Miner. Mh. 7, pp. $173-176$.

Knox, R.W.O'B. 1984: Nannoplankton zonation and the Paleocene/Eocene boundary beds of NW Europe: an indirect correlation by means of volcanic ash layers. J. geol. Soc. London 141, pp. 993-999.

Kronborg, C. \& Knudsen, K.L. 1985: Om Kvartæret ved Rugård: En foreløbig unders $\varnothing$ gelse. Dansk geol. Foren., Arsskrift for 1984, pp. 37-48.

Krüger, J. \& Thomsen, H. Højmark 1984: Morphology, Stratigraphy and Genesis of Small Drumlins in Front of The Glacier Mýrdalsjökull, South Iceland. Journal of Glaciology, Vol. 30, No. 104, pp. 94-105.

Larsen, G. \& Knudsen, B. 1983: Geologiske forhold under havbunden ud for Glatved ved Djurslands østkyst. Dansk geol. Foren., Arsskrift for 1982, pp. 27-33.

Mangerud, J., Andersen, S.T., Berglund, B.E. \& Donner, J.J. 1974: Quaternary stratigraphy of Norden, a proposal for terminology and classification. Boreas 3, pp. 109-128.

Mertz, E.L. 1924: Oversigt over de sen- og postglaciale Niveauforandringer i Danmark. Danm. geol. Unders. II. Rk., $41,49 \mathrm{p}$.

Milthers, V. 1919: Mergelen i Djursland. Danm. geol. Unders. III. Rk., 18, $41 \mathrm{p}$.

Nielsen, P.E. 1981: Till fabric reorientated by subglacial shear. Geol. Fören. i Stockh. Förh., Vol. 103, pp. 383-387.

Petersen, K. Strand 1978: Applications of glaciotectonic analysis in the geological mapping of Denmark. Danm. geol. Unders., Arbog 1977, pp. 53-61.

Petersen, K. Strand 1984: Stratigraphical Position of 
Weichselian Tills in Denmark. In: L.-K. Königsson (Ed.) Ten Years of Nordic Till Research. Striae, Vol. 20, pp. 383-387. Petersen, K. Strand 1985a: Late Weichselian and Holocene Marine Transgressions in Northern Jutland, Denmark. Eiszeitalter u. Gegenwart 35, pp. 71-78.

Petersen, K. Strand 1985b: The Late Quaternary History of Denmark. The Weichselian Icesheets and Land/Sea Configuration in the Late Pleistocene and Holocene. J. Danish Archaeol. 4, pp. 7-22.

Rasmussen, L.B., Dinesen, A., Henriksen, S.E., Bang, I., Stenestad, E., Buch, A.,, Christensen, O.B., Michelsen, 0.\& Jacobsen, F.L. 1971: Dybdeboringen Rønde nr. 1 på Djursland. Danm. geol. Unders. III. Rk., 39, 123 p.

Rasmussen, H.W. 1977: Geologi på Mols. Danm. geol. Unders.

Serie A, 4, $22 \mathrm{p}$.

Rasmussen, L. Aabo 1975: Kineto-stratigraphic glacial drift units on Hindsholm, Denmark. Boreas 4, pp. 209-217.

Sorgenfrei, T. \& Buch, A. 1964: Deep Tests in Denmark 1935-1959. Danm. geol. Unders. III. Rk., 36, 146 p.

Sønderskov, C. \& Hansen, P.H. 1984: The Vulnerability Project ENV 703 DK, Final Report, Subproject 1: Verification of the Preliminary Vulnerability Maps. Danm. geol. Unders., Intern rapport $12,63 \mathrm{p}$.

Ussing, N.V. 1903: Om Jyllands Hedesletter og Teorierne for deres Dannelse. Kgl. dansk Vidensk. Selsk. Forh., 2, pp. 99-165.

Ussing, N.V. 1907: Om Floddale og Randmoræner i Jylland. Kgl. Danske vidensk. Selsk. Forh. 4, pp. 161-213.

Aaby, B. 1986: Norddjurslands landskabsudvikling gennem 7000 år. Antikvariske Studier 4, pp. 60-84.

Arhus Amtskommune, Amtsvandvæsnet 1977: Vandforsyningsplanlægning . 


Skineto-stratigraphic drift unit
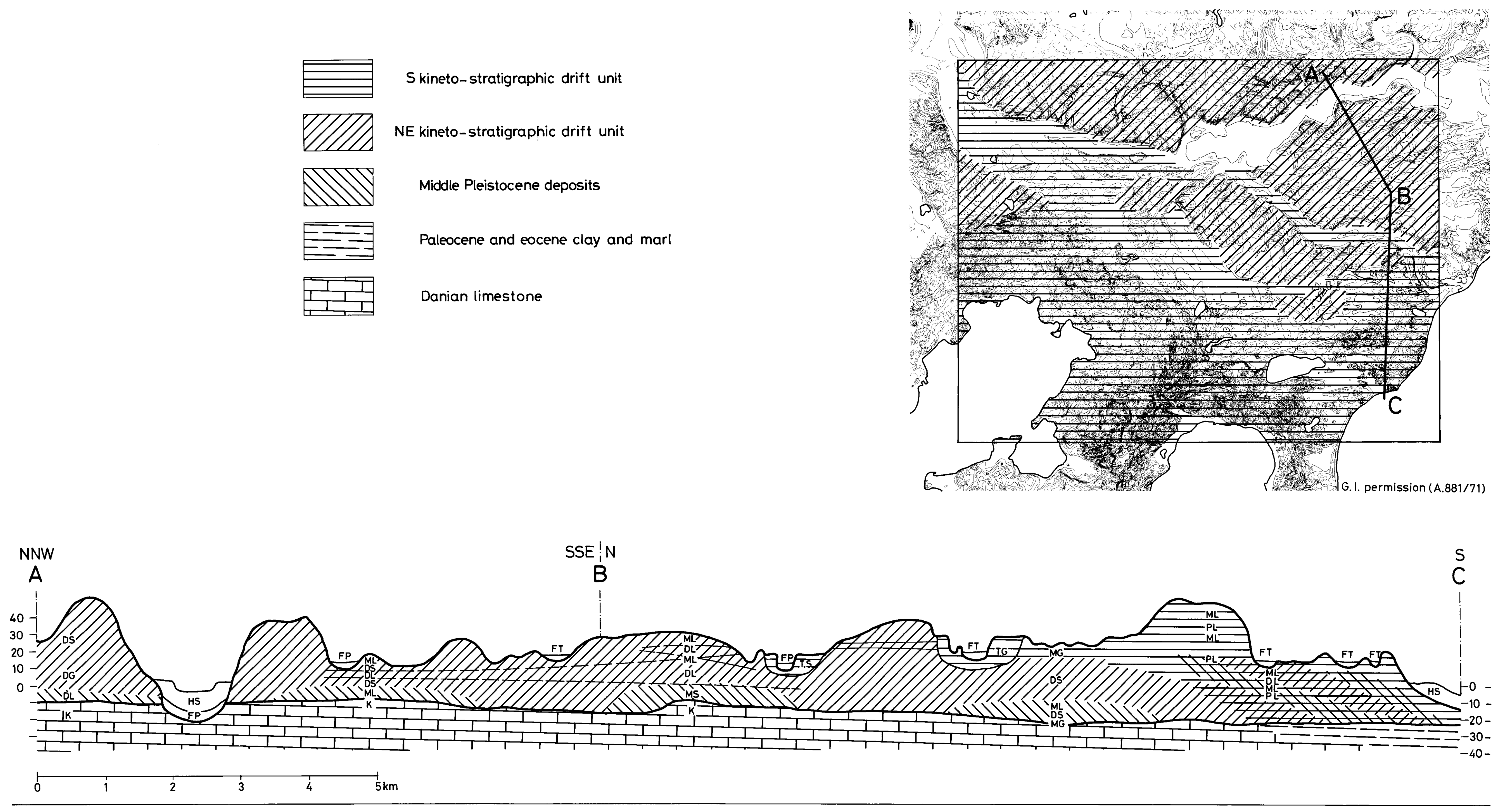
等,

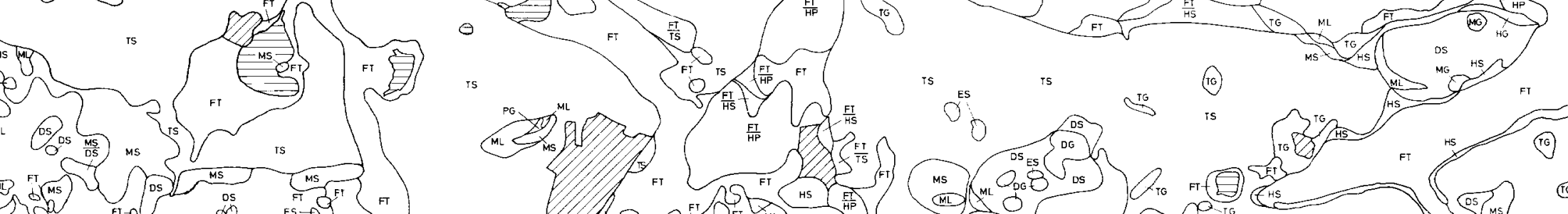

等,

S

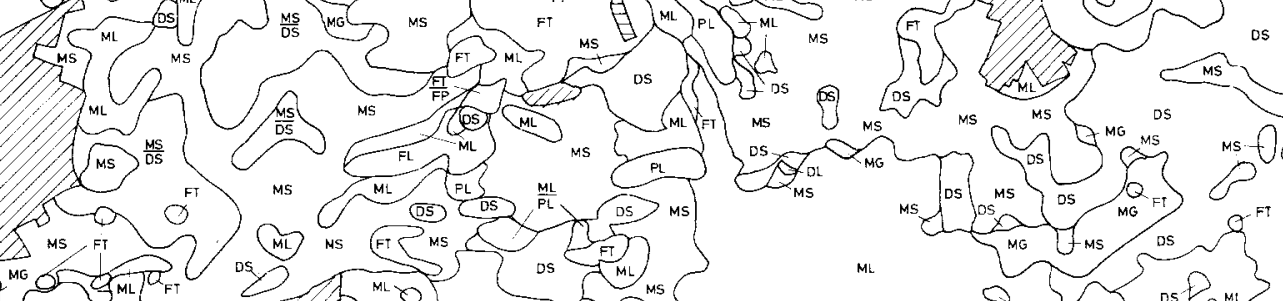

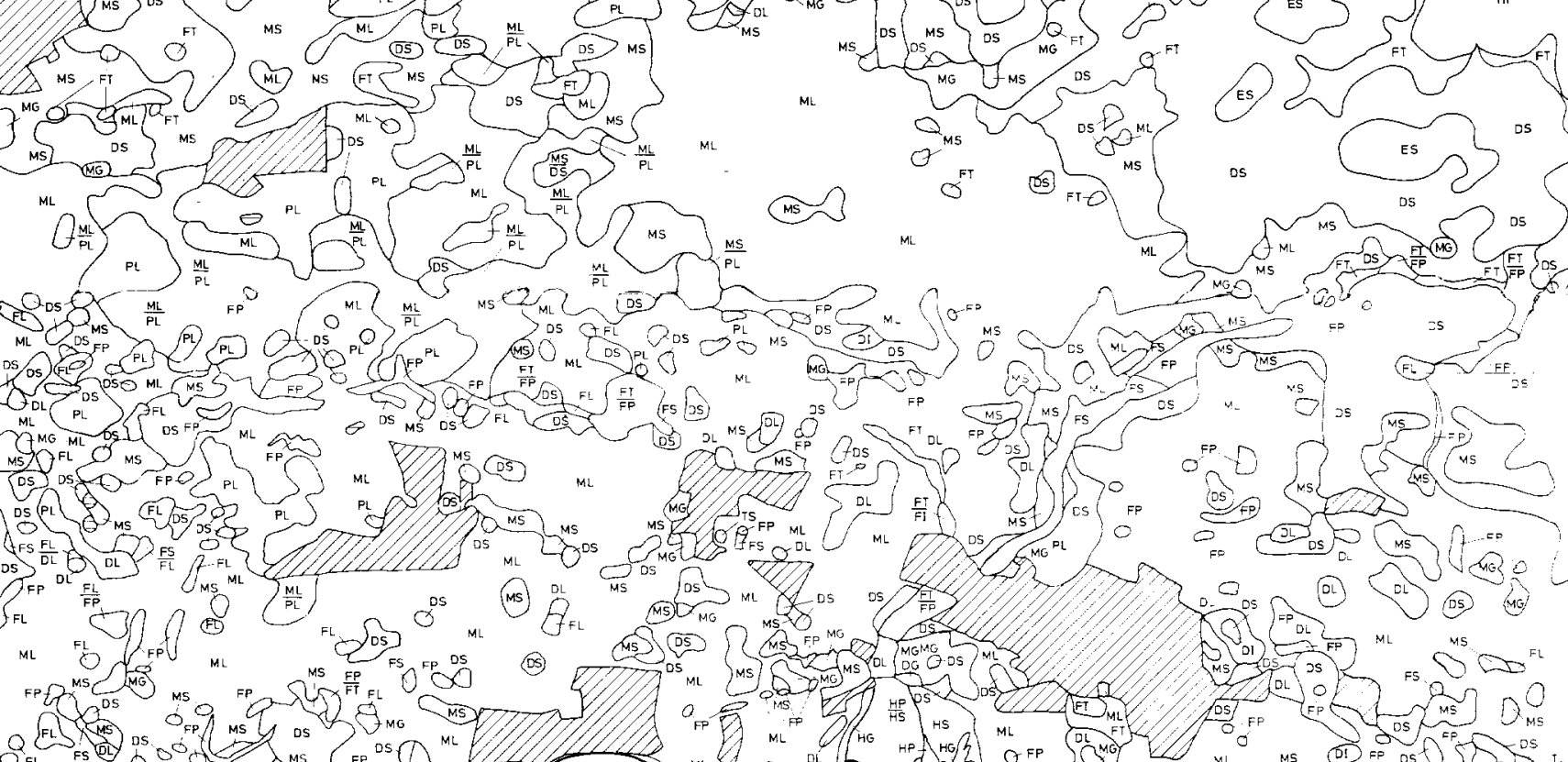

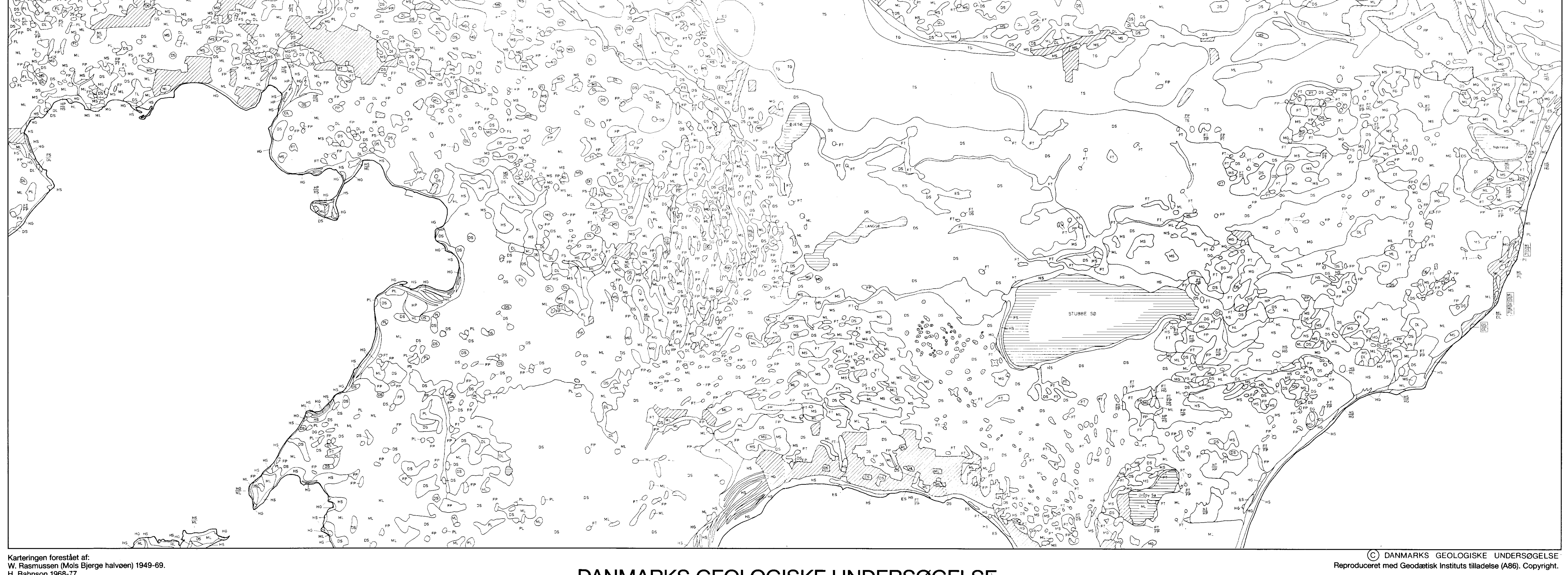


In this book the dynamic features observed during the geological mapping procedure have formed the basis of the Pleistocene stratigraphy following the kineto-stratigraphic concept. A kineto-stratigraphic drift unit can be defined as comprising the sediments deposited by a single ice sheet or ice advance that possess a characteristic pattern and direction of movement.

The Holocene strata comprising the Littorina fjord stages can be regarded as a consequence of changing sea-level stands.

Ministry of the Environment

Geological Survey of Denmark

Thoravej 31

DK 2400 Copenhagen NV

Denmark

Phone +451106600 